\title{
Ni-sepiolite-falcondoite in garnierite mineralization from the Falcondo Ni-laterite deposit, Dominican Republic
}

\author{
E. TAULER ${ }^{1} *$, J. A. PROENZA ${ }^{1}, \mathrm{~S} \cdot \mathrm{GALI}^{1}, \mathrm{~J} . \mathrm{F} \cdot \mathrm{LEWIS}^{2}, \mathrm{M} \cdot \mathrm{LABRADOR}^{1}$, \\ E. GARCÍA-ROMERO ${ }^{3}, \mathrm{M} \cdot \mathrm{SUAREZ}{ }^{4}, \mathrm{~F} \cdot \mathrm{LONGO}^{5} \mathrm{AND}_{\mathrm{A}} \mathrm{G} \cdot \mathrm{BLOISE}^{5}$ \\ ${ }^{1}$ Departament de Cristallografia, Mineralogia i Dipòsits Minerals, Facultat de Geologia, Universitat de Barcelona, \\ C/ Marti i Franquès s/n, E-08028 Barcelona, Spain, ${ }^{2}$ Department of Earth and Environmental Sciences, The George \\ Washington University, Washington, D.C. 20052, USA, ${ }^{3}$ Departamento de Cristalografia y Mineralogía, Universidad \\ Complutense de Madrid, E-28040, Madrid, Spain, ${ }^{4}$ Departamento de Geología, Universidad de Salamanca, E-37008, \\ Salamanca, Spain, ${ }^{5}$ Falcondo XStrata Nickel, Box 1343, Santo Domingo, Dominican Republic
}

(Received 24 December 2008; revised 31 July 2009; Editor: Javier Cuadros)

\begin{abstract}
New chemical and structural data on sepiolite-falcondoite in garnierite veins from the Falcondo Ni-laterite deposits, central Dominican Republic, are reported. Samples of Ni-sepiolitefalcondoite vary in colour from whitish green to green depending on the $\mathrm{NiO}$ content (wt.\%) and the amount of silica present. The texture is normally schistose and friable but samples with considerable quartz and/or amorphous silica are compact and hard. Back-scattered electron images indicate that the samples are composed of at least three generations of Ni-sepiolite-falcondoite. The extreme refined cell parameters for Ni-sepiolite-falcondoite vary from $13.400(2), 27.006(4), 5.273(1) \AA$ to 13.340(3), 27.001(6), 5.267(1) $\AA$ (space group Pncn). As the Ni content increases there is a small reduction in the $a$ parameter. Chemical compositions determined by electron probe microanalysis cover a large interval of the Ni-sepiolite-falcondoite solid solution $\left(\mathrm{Fal}_{3}\right.$ and $\left.\mathrm{Fal}_{77}\right)$. Individual samples show a considerable range in composition with the widest range determined in one sample from 4.63 to 22.40 wt.\% $\mathrm{NiO}$.
\end{abstract}

KEYwords: Ni-sepiolite, falcondoite, garnierite, crystal chemistry, Falcondo, Ni-laterites, Dominican Republic.

$\mathrm{Ni}$-sepiolite, the properties of which were described for the first time by Caillère (1936) and Caillère \& Hénin (1963) for a sample from New Caledonia, is a common constituent of garnierite mineralization in hydrous silicate-type lateritic nickel deposits (e.g. Brand et al., 1998; Freyssinet et al., 2005). Garnierite is used here as a field term referring to a wide variety of clay-like Ni-bearing hydrous silicates with a characteristic green colour. It

* E-mail: esperancatauler@ub.edu

DOI: 10.1180 /claymin.2009.044.4.435 usually occurs as an intimate mixture that commonly includes two or more of the following minerals: serpentine, talc, sepiolite, smectite and chlorite (e.g. Springer, 1974; Brindley et al., 1979; Gleeson et al., 2004). The minerals form several solid-solution series that can be discussed in terms of the system Mg-Ni-Si (Proenza et al., 2008). The occurrence and properties of one of these solid solutions, sepiolitefalcondoite, is the subject of this paper.

According to the ' $50 \%$ rule' for mineral nomenclature recommended by the Commission on New Minerals and Mineral Names of the International Mineralogical Association (Nickel, 1992) and assuming a complete solid-solution 
series between sepiolite and falcondoite, the name sepiolite applies to the compositional range from $\left[\mathrm{Mg}_{8} \mathrm{Si}_{12} \mathrm{O}_{30}(\mathrm{OH})_{4}\left(\mathrm{OH}_{2}\right)_{4} \cdot 8\left(\mathrm{H}_{2} \mathrm{O}\right)\right]$ to $\left[\left(\mathrm{Mg}_{4} \mathrm{Ni}_{4}\right)\right.$ $\left.\mathrm{Si}_{12} \mathrm{O}_{30}(\mathrm{OH})_{4}\left(\mathrm{OH}_{2}\right)_{4} .8\left(\mathrm{H}_{2} \mathrm{O}\right)\right]$ with 20.86 wt.\% $\mathrm{NiO}$. The name falcondoite applies to the compositional range $\left[\mathrm{Ni}_{8} \mathrm{Si}_{12} \mathrm{O}_{30}(\mathrm{OH})_{4}\left(\mathrm{OH}_{2}\right)_{4} .8\left(\mathrm{H}_{2} \mathrm{O}\right)\right]$ to $\left[\left(\mathrm{Ni}_{4} \mathrm{Mg}_{4}\right) \mathrm{Si}_{12} \mathrm{O}_{30}(\mathrm{OH})_{4}\left(\mathrm{OH}_{2}\right)_{4} \cdot 8\left(\mathrm{H}_{2} \mathrm{O}\right)\right]$ with 38.03 wt. $\%$ NiO. The term Ni-sepiolite is used to distinguish this particular variety of sepiolite with up to 20.86 wt. $\% \mathrm{NiO}$ from other sepiolites with different compositions (e.g. ferriferous, aluminous and manganiferous compositional varieties: Caillère \& Henin, 1961; Chukanova et al., 2002). Falcondoite, approved by the IMA in 1976, is apparently a rare mineral species, reported only from the Ni-laterite deposits at the Falcondo mine in the Dominican Republic. A review of the literature showed there have been no detailed studies of falcondoite since the publication by Springer (1976).

Sepiolite (sensu stricto) refers to the hydrous magnesian silicate clay mineral with the structural formula $\left[\mathrm{Mg}_{8} \mathrm{Si}_{12} \mathrm{O}_{30}(\mathrm{OH})_{4}\left(\mathrm{OH}_{2}\right)_{4} \cdot 8\left(\mathrm{H}_{2} \mathrm{O}\right)\right]$; it is soft and fibrous. Pure uncontaminated sepiolite is white in colour but may be pinkish white or greenish yellow and has an earthy or, sometimes, waxy lustre (Caillère \& Henin, 1963). Sepiolite occurs in a wide variety of geological environments from sedimentary to hydrothermal (Jones \& Galán, 1988) and has recently been described in volcanosedimentary lacustrine environments in Turkey (Kadir et al., 2002). Sepiolite has a layer structure formed of ribbons of 2:1 phyllosilicate modules, but with tetrahedral apices pointing in opposite directions in adjacent ribbons. Unlike other phyllosilicates it lacks continuous octahedral sheets. The structure has large channels parallel to the phyllosilicate ribbons that are partially occupied by $\mathrm{H}_{2} \mathrm{O}$ molecules. In the structural formulae, the coordinated or crystallographically bound water at the edges of the ribbons is designated as $\left(\mathrm{OH}_{2}\right)_{4}$ and is distinguished from the zeolitic water designated as $\mathrm{H}_{2} \mathrm{O}$ that occupies the channels (Brauner \& Preisinger, 1956).

In his description of the composition and structural variations in garnierites Springer (1974) reported an analysis of Ni-sepiolite with 17.3 wt.\% $\mathrm{NiO}$ from the Noume mine, New Caledonia, and Manceau et al. (1985) described the properties of a Ni-sepiolite $(12.8 \mathrm{wt} . \% \mathrm{NiO})$ in garnierites from the Poro Mine, New Caledonia. The analyses of garnierites by Springer (1974) are significant because they are probably the first published analyses of garnierite minerals determined by microprobe. He did not report any variation in the composition of individual Ni-sepiolite samples or other garnierites. However, he showed a range in composition in sepiolite and garnierites in his fig. 1 (Springer, 1974). An origin for Ni-sepiolite and other garnierites from New Caledonia was proposed by Lacroix (1893-95) as derived by superfical alteration of peridotites. Ni-sepiolite (10.6 wt.\% $\mathrm{NiO})$ is a major Ni-bearing phase in the weathering profile of the Cerro Matoso silicate Ni-laterite deposit in northwest Colombia (Gleeson et al., 2004) and sepiolite (with $1.55 \mathrm{wt} \% \mathrm{NiO}$ ) was reported in mm-thick veins and as thin coatings on the slickensided surface of fractures, in the lateritc deposits at Nickel Mountain, Oregon (Hotz, 1964). In addition, Ni-sepiolite is found throughout the saprolite horizons of the Marlborough Ni-laterite deposits, Australia (Foster \& Eggleton, 2002) and lateritic weathering profiles of the Sukinda ultramafic rocks (India; Som \& Joshi, 2002).

In this paper, its mode of occurrence in a lateritic profile and new chemical and structural data are reported for the $\mathrm{Ni}$-sepiolite-falcondoite in garnierite veins from the Falcondo Ni-laterite deposits, Central Dominican Republic.

\section{GEOLOGICAL BACKGROUND: THE FALCONDO Ni-LATERITE PROFILE}

The Loma Caribe peridotite is the main belt of ophiolitic peridotites that crop out in the Cordillera Central of the Dominican Republic (Fig. 1a). The peridotite body is $\sim 4-5 \mathrm{~km}$ wide, extends for $95 \mathrm{~km}$, and consists mainly of harzburgite with subordinate dunite and lherzolite (Lewis et al., 2006; Proenza et al., 2007). These serpentinized peridotites have given rise to Ni-laterite soils. The lateritization began in the early Miocene, when serpentinized peridotites were exposed to weathering and erosion. The Ni-laterite deposits are classified as the hydrous silicate-type. The main Ni-bearing minerals are hydrated $\mathrm{Mg}-\mathrm{Ni}$ silicates (serpentine and 'garnierite') occurring in the saprolite horizon below a relatively thin cover of limonite (Lithgow, 1993; Lewis et al., 2006). Total $\mathrm{Ni}$ reserves are estimated at 46,458 (000's Dry Metric Tons) at a grade of 1.21 wt.\% Ni (Falcondo Operation Reports, December 2008).

According to the criteria used by Falcondo geologists in their mining operation, six zones of 

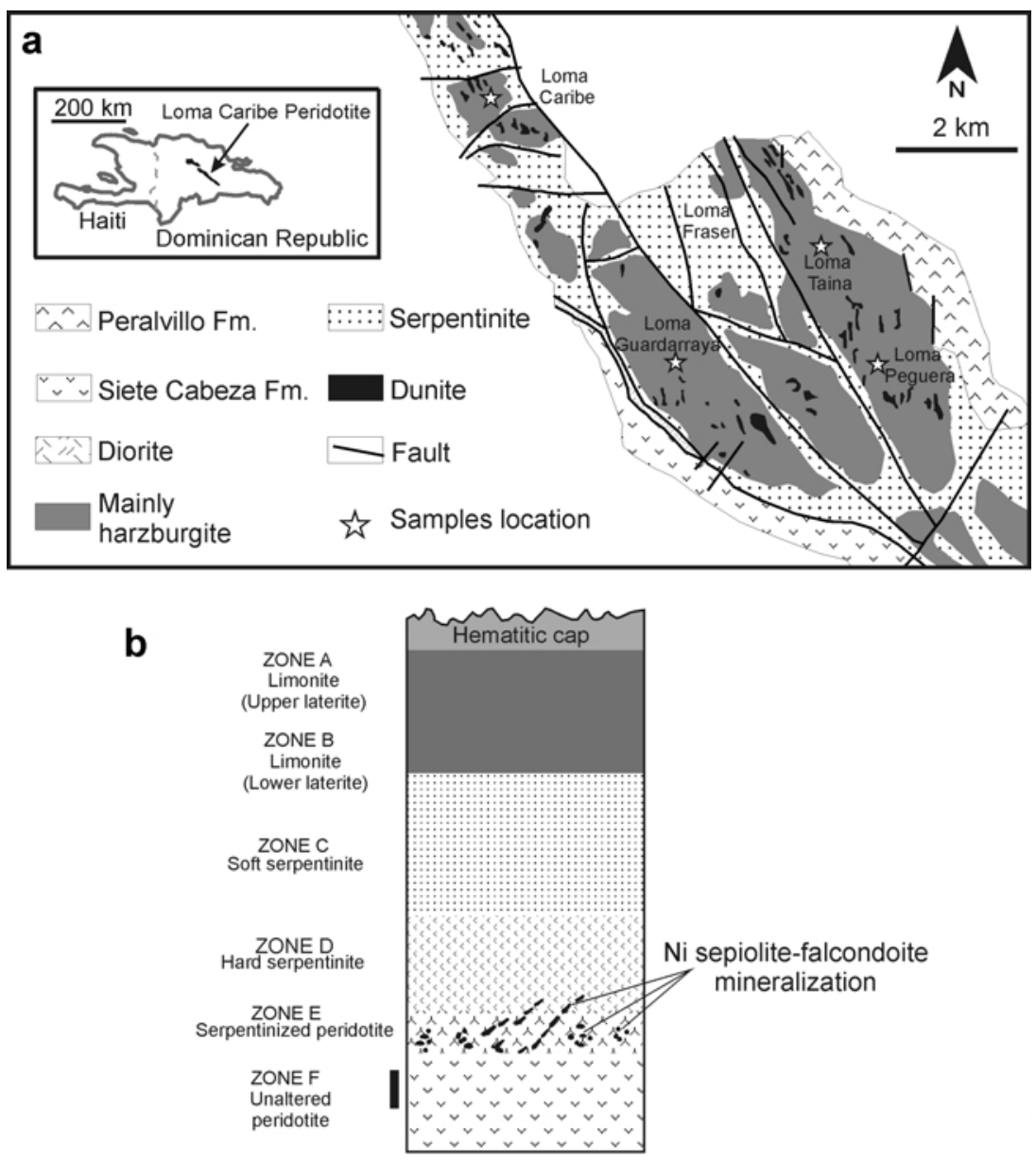

Water-table

FIG. 1. (a) Geographical location and geological sketch-map of the south-central part of the Loma Caribe peridotite showing the location of the studied area (modified from Haldemann et al., 1979). (b) Ideal laterite profile showing the six horizons (zones) defined at the Falcondo mine, central Dominican Republic.

ore-grade material have been recognized, based on $\mathrm{Ni}$ and Fe contents, texture, and proportion of rocky fragments (Haldemann et al., 1979; Lithgow, 1993; Lewis et al., 2006; Fig. 1b). The zones A and B correspond to the upper limonite or laterite sensu stricto zone, whereas zones labelled $\mathrm{C}$ to $\mathrm{E}$ represent the lower saprolitic zone that have been recognized in Ni-laterite deposits in other parts of the world (e.g. Elias, 2002).

\section{MODE OF OCCURRENCE}

$\mathrm{Ni}$-sepiolite-falcondoite and other garnierite minerals have been found to occur widely in the
Falcondo mine (Springer, 1974; Lithgow, 1993). Detailed examination of a large number of samples has shown the mineralogy of the ores to be highly variable, consisting of lizardite-nepouite, kerolite (talc)-pimelite (willemseite), and sepiolite-falcondoite (Proenza et al., 2008).

Unfortunately, little attention has been given to the mode of occurrence of the garnierites and no record has been kept since mining began in 1970 . Typically, the garnierites occur as vein-filling fractures in the harder serpentinized peridotites of zones $\mathrm{D}, \mathrm{E}$ and $\mathrm{F}$, in the lower part of the laterite profile (Fig. 1b). This includes the lower part of the saprolite zone, where hard blocks of slightly 
weathered rock occur below the soft saprolite and limonite. As in other parts of the world (e.g. New Caledonia; Cluzel \& Vigier, 2008), several types of field occurrence can be distinguished (Fig. 2). Tension fracture-fillings are the most common occurrence. These can be found as a concentration of anastomizing veins or as a boxwork fabric. Other occurrences include thin coatings on joints, often displaying slickensides, and breccias.

White to pale green-tinted Ni-sepiolite (+quartz) commonly occurs without falcondoite or other garnierite minerals in $\mathrm{mm}$ to $\mathrm{cm}$-thick veins. Examples of the thin $\mathrm{Ni}$-sepiolite veins can be found in most of the mined areas at Falcondo (e.g. Loma Peguera, Loma Caribe) (Fig. 1a). Ni-sepiolite and falcondoite are found together as thicker masses in veins up to $30 \mathrm{~cm}$ wide and it is these samples that we have examined here in detail (Fig. 3).

\section{ANALYTICAL TECHNIQUES}

Four representative samples (labelled F0, F1, F2 and F3) belonging to the sepiolite-falcondoite series were studied in detail using optical microscopy, X-ray fluorescence (XRF), X-ray powder diffraction
(XRD), thermogravimetric analysis (TGA), scanning electron microscopy (ESEM and FESEM), electron microprobe (EMP), and transmission electron microscopy (TEM). In addition, other samples were analysed by EMP (G1) and XRF and TEM (F6, F7).

Analyses by XRF were determined with a Panalytical (Philips) PW2400 spectrometer with a $\mathrm{Rh}$ X-ray tube operated at $60 \mathrm{kV}$ and $125 \mathrm{~mA}$.

Particle morphology and microtextural features of the studied samples were examined on fresh fractured material and polished thin sections on an ESEM Quanta 200 FEI, XTE 325/D8395. This equipment is housed at the Serveis Cientificotècnics of the University of Barcelona. Further details of particle morphology and textural features on a nanometer scale were studied by FESEM using a JEOL, JSM 6335 Field Emission microscope at the Centro de Ayuda de Investigaciones (CAI) of Electron Microscopy 'Luis Bru' (Complutense University, Madrid). Prior to examination, freshly fractured surfaces were air dried and coated with gold under vacuum.

TG analyses were carried out with a Netzsch STA $409 \mathrm{C} / \mathrm{CD}$ instrument, on $\sim 80 \mathrm{mg}$ of sample ground to $<100 \mu \mathrm{m}$, in an $\mathrm{Al}_{2} \mathrm{O}_{3}$ crucible under a
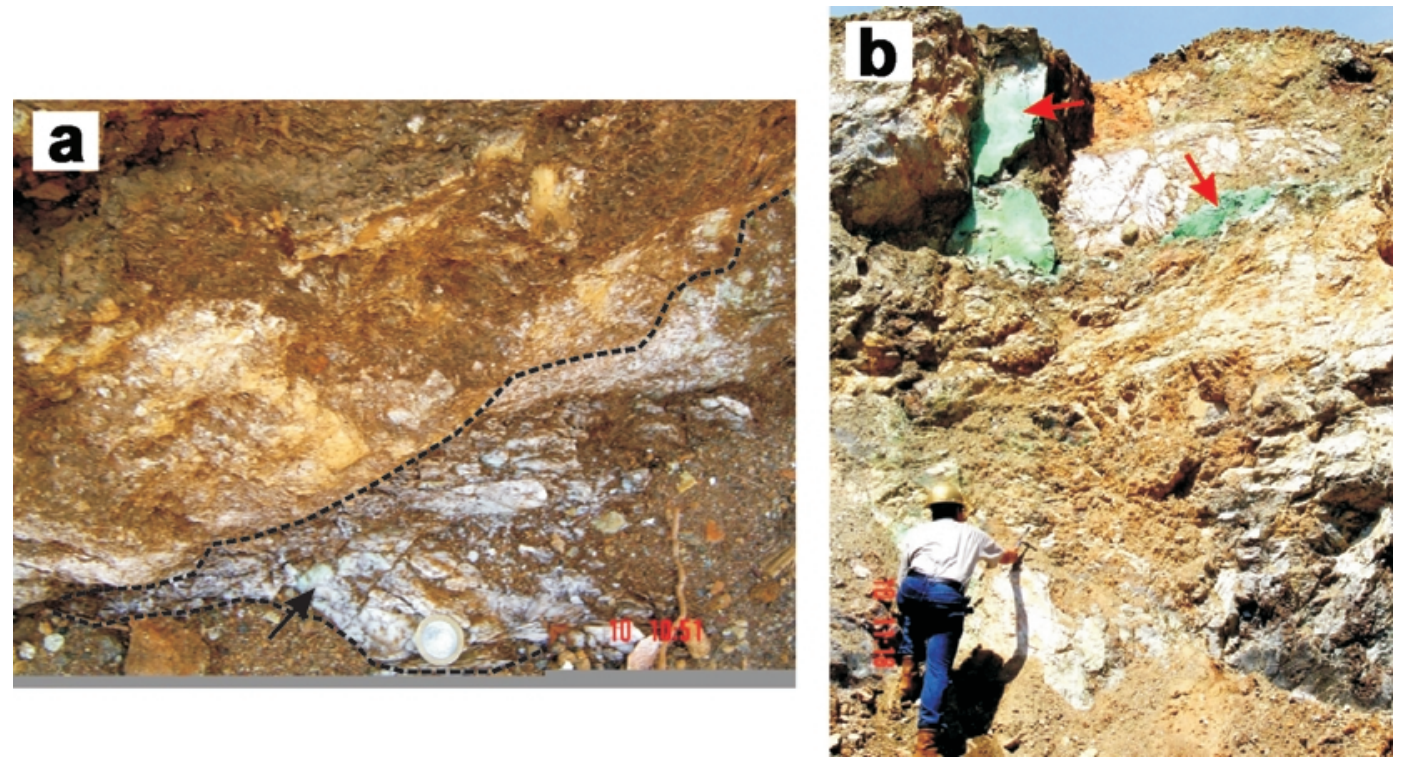

FIG. 2. (a) Ni-sepiolite (mainly falcondoite) outcrop following a fracture, showing sub-parallel joints, oriented E-W on a mining bench in the Loma Guardarraya area. Falcondo Mining Block No. G0067. (b) Ni-sepiolitefalcondoite vein $\sim 4 \mathrm{~cm}$ thick following a fracture in a highly tectonized zone. Falcondo Mining Block No. G0062. 

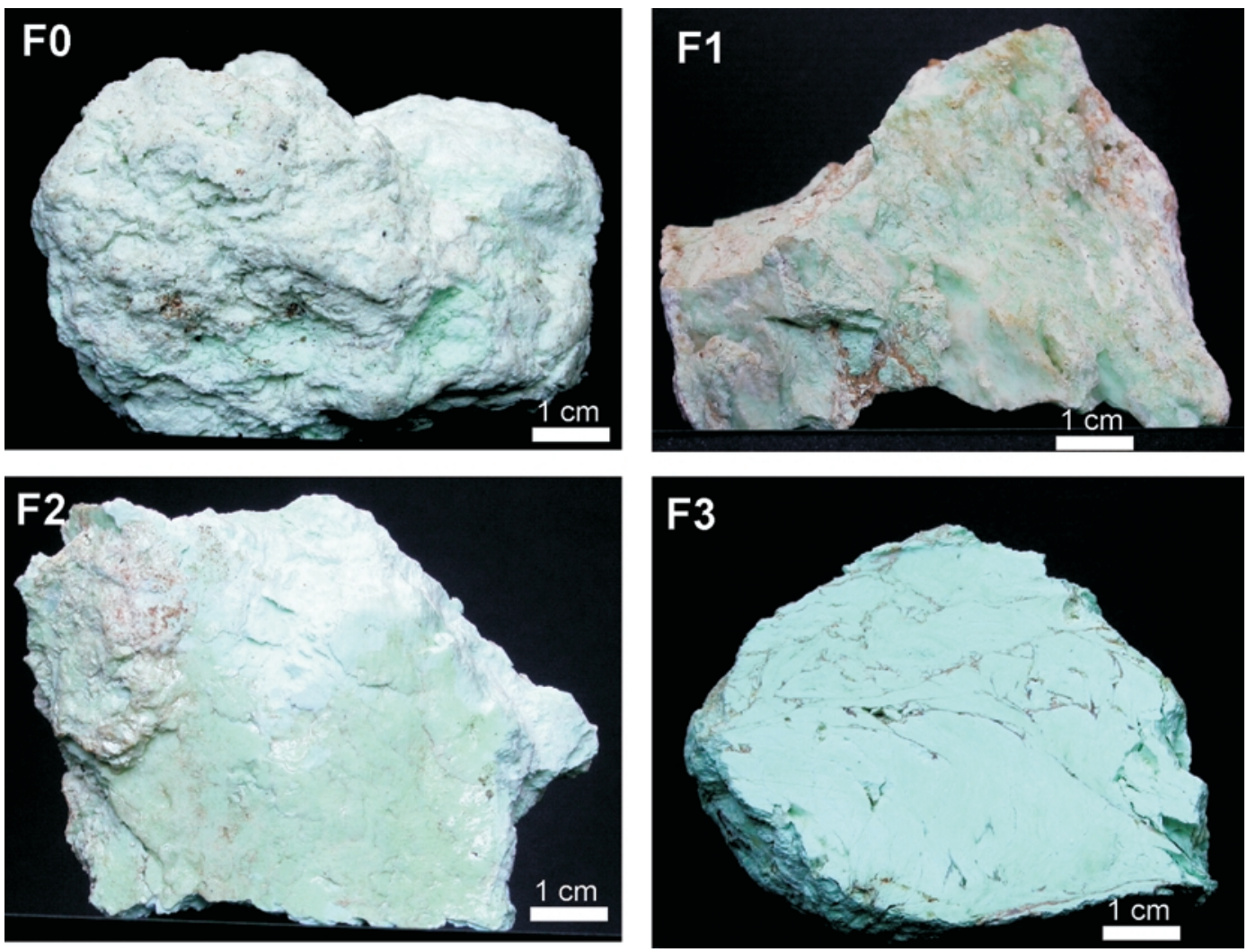

FIG. 3. Photographs of hand specimens of the four samples studied in detail. F0: Intercalated white and pale green, schistose, friable soft material identified as Ni-sepiolite and minor quartz. F1: Hard intercalated foliated white to greenish material, in places separated along fractures by pale brownish material that is mixed with fragments of the green material. White to greenish material identified as Ni-sepiolite with quartz. F2: Hard waxy whitish-green foliated material forming a large block about $2 \mathrm{~cm}$ thick. Thin layer of white material ( 1 mm) forms the base. Whitish-green material composed of Ni-sepiolite-falcondoite and intercalated quartz. F3: Foliated and partly brecciated, compacted relatively hard, green material composed of Ni-sepiolite-falcondoite and quartz.

dry air atmosphere with a flow rate of $80 \mathrm{ml} \mathrm{min}^{-1}$, in a range between 22 and $1000^{\circ} \mathrm{C}$ at $5^{\circ} \mathrm{C} \mathrm{min}^{-1}$.

XRD data were collected with a Panalytical X'Pert PRO MPD X-ray diffractometer with monochromatized incident $\mathrm{Cu}-K \alpha_{1}$ radiation at $45 \mathrm{kV}$ and $40 \mathrm{~mA}$, and equipped with a PS detector with amplitude of $3^{\circ}$. The patterns were obtained by scanning powders from $4-80^{\circ} 2 \theta$ on samples crushed in an agate mortar to a particle size $<40 \mu \mathrm{m}$. Two data sets were obtained with different conditions: (a) a scan time of $300 \mathrm{sec}$ at a step size of $0.0170^{\circ}(2 \theta)$ and a fixed divergence slit of $0.25^{\circ}$; (b) a scan time of $50 \mathrm{~s}$ at a step size of $0.0170^{\circ}(2 \theta)$ and variable divergence slit. The patterns of samples on oriented mounts were collected as follows: (a) air-dry, scanning from $2-80^{\circ} 2 \theta$; (b) on samples saturated with ethylene glycol and scanning from $2-30^{\circ} 2 \theta$; and (c) by heating the same sample up to $550^{\circ} \mathrm{C}$ and scanning from $2-30^{\circ} 2 \theta$, at a step size of $0.0170^{\circ}$ and scan time of $50 \mathrm{~s}$. Quantitative mineral phase analyses of the samples were obtained by full profile Rietveld refinement using XRD data. The software used was TOPAS V2.1.

Microprobe analyses were carried out over selected areas on polished thin sections and polished sections. EMP analyses of the Ni-sepiolite-falcondoite samples were carried out with a four-channel CAMECA SX50 electron microprobe at the Serveis Cientificotècnics of the 
University of Barcelona. The analytical conditions were $20 \mathrm{kV}$ accelerating voltage, $10 \mathrm{~mA}$ beam current, $2 \mu \mathrm{m}$ beam diameter, and counting time of $10 \mathrm{~s}$ per element. Calibrations were performed using natural and synthetic reference materials: diopside $(\mathrm{Si})$, periclase $(\mathrm{Mg}), \mathrm{NiO}(\mathrm{Ni}), \mathrm{Fe}_{2} \mathrm{O}_{3}(\mathrm{Fe})$, wollastonite $(\mathrm{Ca})$, albite $(\mathrm{Na})$, orthoclase $(\mathrm{K})$, rhodonite $(\mathrm{Mn})$, rutile $(\mathrm{Ti}), \mathrm{Cr}_{2} \mathrm{O}_{3}(\mathrm{Cr}), \mathrm{Al}_{2} \mathrm{O}_{3}(\mathrm{Al})$.

Analyses by Analytical Electron Microscopy (AEM) were carried out by Transmission Electron Microscopy (TEM) at the CAI of Electron Microscopy 'Luis Bru' (Complutense University, Madrid). TEM observations were performed by depositing a drop of diluted suspension on a grid with collodion. Data were obtained using a JEOL 2000 FX microscope equipped with a double-tilt sample holder (up to a maximum of $\pm 45^{\circ}$ ) at an acceleration voltage of $200 \mathrm{kV}$, with $0.5 \mathrm{~mm}$ zetaaxis displacement and $0.31 \mathrm{~nm}$ point-to-point resolution. The microscope incorporates an OXFORD ISIS energy dispersive X-ray spectrometer $(136 \mathrm{kV}$ resolution at $5.39 \mathrm{kV})$ and has its own software for quantitative analysis. The atomic $\%$ was calculated by the Cliff-Lorimer thin-film ratio criteria (Lorimer \& Cliff, 1976). The structural formulae for analysed particles were calculated on the basis of $\mathrm{O}_{30}(\mathrm{OH})_{4}$. All the Fe present was considered as $\mathrm{Fe}^{3+}$ (owing to the limitation of the technique) but the possible existence of $\mathrm{Fe}^{2+}$ cannot be excluded.

\section{RESULTS}

\section{Fibre morphology and textural features}

Under the optical microscope, the studied samples are seen to be composed of aggregates of fibrous Ni-sepiolite-falcondoite with quartz (Fig. 4a, sample F0). These aggregates are usually bent, fractured and wavy (Fig. 4b, sample F3). The bent sepiolite-falcondoite filaments are $\sim 1.2 \mathrm{~mm}$ in length, and $<0.2 \mathrm{~mm}$ wide. In some cases, $\mathrm{Ni}$ sepiolite masses include fragments of saprolitized peridotite and relict chromite grains.

Secondary electron (SE) images show that Nisepiolite-falcondoite occurs as thin fibrous aggregates. In general, they have a characteristic threadlike morphology (Fig. 5a, sample F3). Hairy filaments of Ni-sepiolite-falcondoite are seen to grow roughly in parallel. On surfaces formed by the fibres, quartz may nucleate and grow perpendicular to these surfaces (Fig. 5b, sample F2). In the SE
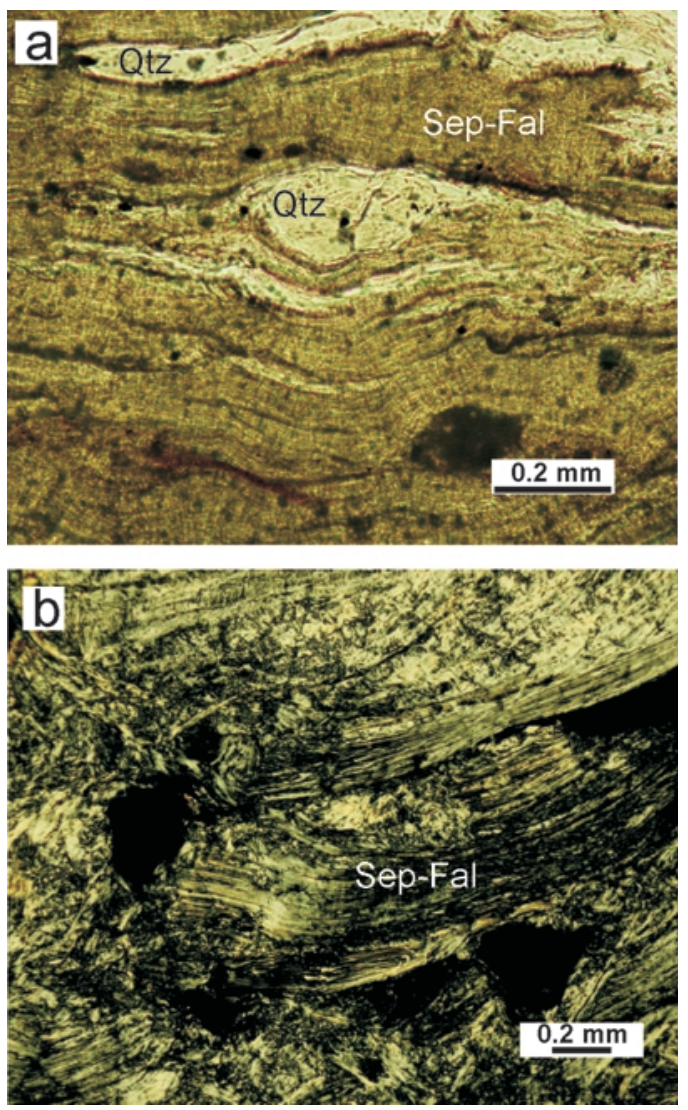

FIG. 4. Photomicrographs (optical microscope) showing overall textures in Ni-sepiolite-falcondoite samples. (a) Pronounced schistose texture in Ni-sepiolitefalcondoite. Late-formed quartz veinlets penetrated the fibrous material parallel to the fabric and filled open pore spaces. The material was later deformed by syntectonic movement involving shear (sample F0; plane-polarized light). (b) Solid mass of deformed fibrous $\mathrm{Ni}$-sepiolite-falcondoite. Note the random orientation of the mini-fractures criss-crossing the fibres and small dark angular impure fragments of chromite (sample F3; planed-polarized light, crossed polars).

images at a greater magnification, microcrystalline spheres of silica appear intercalated with and at the termination of the fibres (Fig. 5c, sample F2).

TEM images show a characteristic fibrous morphology (Fig. 5d). The samples are composed of very long fibres or bundles of fibres. Their size depends on the breaking produced by the dispersion procedure, but it is possible to confirm that the 

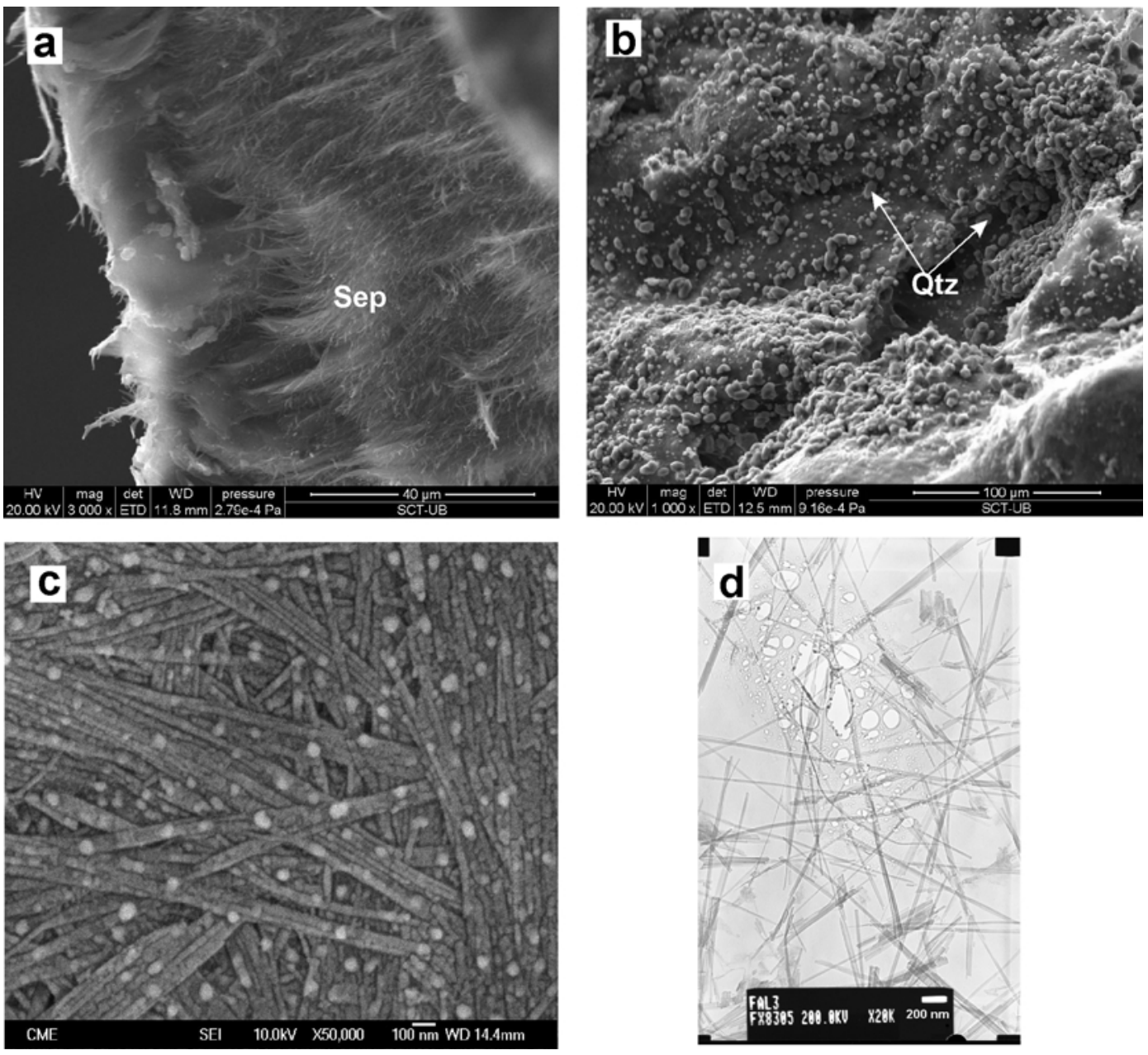

FIG. 5. (a) SEM image illustrating the nature of sepiolite fibres in sample F3. (b) SEM image of microcrystalline quartz growth on sepiolite-falcondoite masses in sample F2. (c) FESEM image of fibres of Ni-sepiolitefalcondoite with spheres of amorphous silica in sample F2. (d) TEM images of fibres in sample F3.

fibres or bundles of fibres are more than $10 \mu \mathrm{m}$ in length and are 0.01 to $0.1 \mu \mathrm{m}$ in width on average (Fig. 5d, sample F3).

The detailed microtextures on the $4-500 \mu \mathrm{m}$ scale are variable and complex and indicate a complex history of deposition and deformation of the garnierite minerals. Microtextural study by SEM, using back-scattered electrons (BSE), indicates that the studied samples are composed of at least three generations of $\mathrm{Ni}$-sepiolite-falcondoite. Examples of the most common microtextural features are illustrated in Fig. 6. A first generation of sepiolite is Ni-poor (Sep-I in Fig. 6a: dark, smaller atomic number), and has been partially replaced by a second generation rich in Ni (Sep-II in Fig. 6a: light, larger atomic number). This second generation corresponds to falcondoite. Figure $6 \mathrm{~b}$ shows in detail the incipient replacement of Sep-I by Sep-II along grain boundaries and cracks. These two generations of sepiolite-falcondoite are partly corroded and replaced by a later (third) generation of Ni-poor sepiolite (Sep-III in Fig. $6 \mathrm{a}, \mathrm{b}$ and $\mathrm{c}$ ) along the grain boundaries and fractures. Sep-III was formed together with 'chrysoprase', a green cryptocrystalline variety of quartz with $\sim 1.5$ wt.\% $\mathrm{NiO}$ (Fig. $6 \mathrm{~d}$ ). A late 

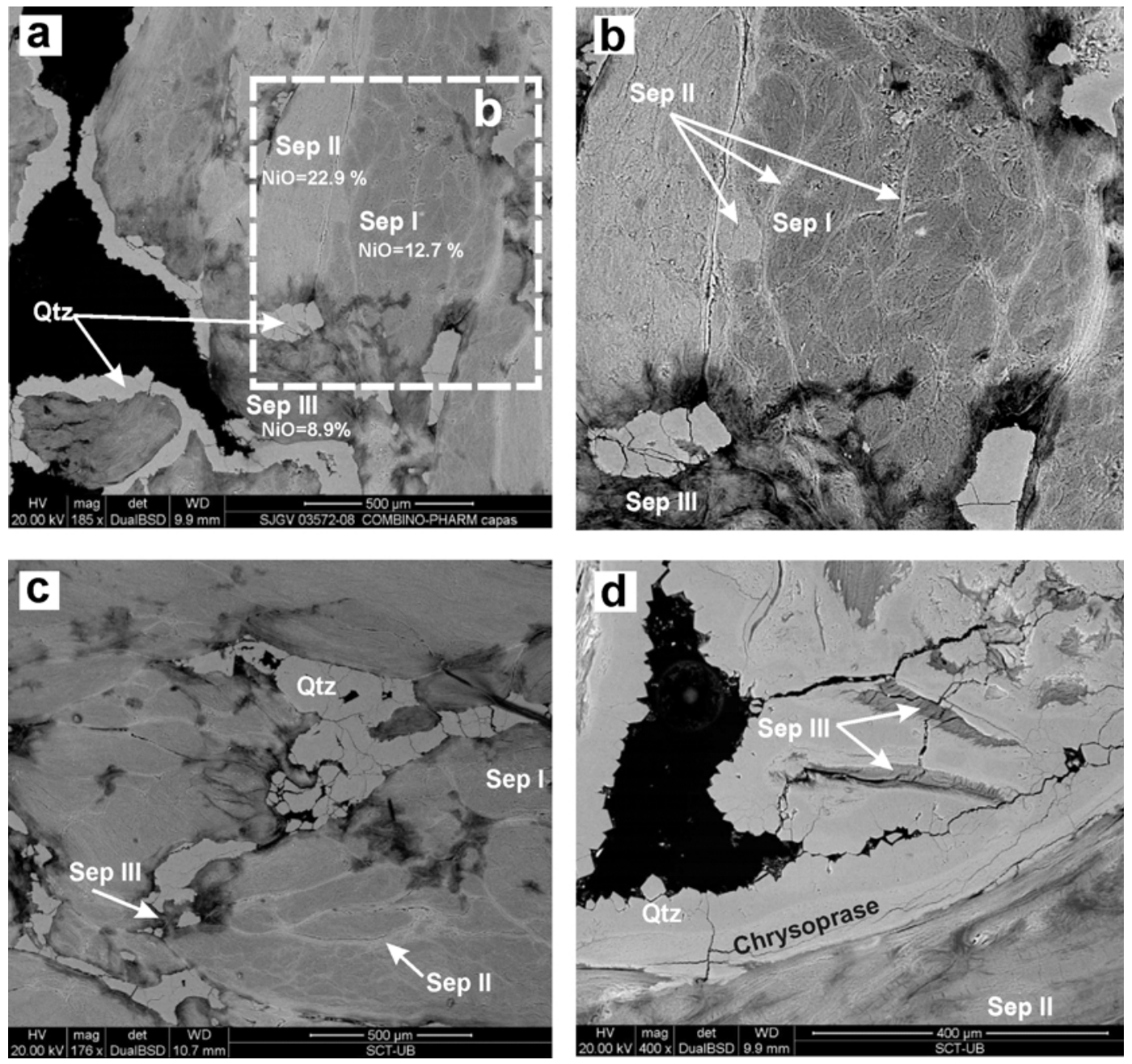

FIG. 6. Back-scattered electron images of the microtextures in samples of Ni-sepiolite-falcondoite. Sep I and Sep III (Ni-poor, medium and dark grey area), Sep II (Ni-rich light grey area) in each image represents successive generations of Ni-sepiolite-falcondoite (see text). Measured amounts of $\mathrm{NiO}$ (wt.\%) for each generation of Sep I, II and III are shown in Fig. 6a. In all cases quartz (Qtz) is the last mineral to crystallize and fills open cavities (see text for explanation).

generation of microcrystalline quartz fills the remaining pore space in the veins (Fig. 6d). Measured amounts of $\mathrm{NiO}$ (wt.\%) for each generation of Sep I, II and III are shown on Fig. 6a. In all cases quartz is the last mineral to crystallize and fills open cavities. Note the narrow rims of Sep II surrounding Sep I and the very narrow rim of Sep III coated with quartz.

These microtextures indicate that the variation in the $\mathrm{Mg} / \mathrm{Ni}$ ratio in the $\mathrm{Ni}$-sepiolite-falcondoite samples is not due to zoning on a small scale as assumed by Springer (1976), but is related to the way in which the Ni-sepiolite-falcondoite solutions were deposited as distinct generations of $\mathrm{Ni}$ sepiolite-falcondoite.

\section{$X$-ray diffraction}

Four selected Ni-sepiolite-falcondoite samples F0, F1, F2 and F3 were analysed by powder XRD including parts of samples with different textures and colour (white and light to darker green). In 
these samples, quartz is always present, mixed with Ni-sepiolite-falcondoite fibres, but it can be partially separated manually. The quartz appearing in the diffractograms represents the amount that could not be excluded. In samples F0, F2 and F3 the amount of Ni-sepiolite-falcondoite present exceeds $92 \%$ and the amount of quartz does not exceed $6 \%$. In comparison sample F1 contains only $32 \%$ Ni-sepiolite. Traces $(<1 \%)$ of talc were found in samples F2 and F3.

The random powder diffractograms of samples F0, F1, F2 and F3 (chemical composition in Table 2) are shown in Fig. 7. All peaks can be unambiguously identified on the basis of the sepiolite structure (Bailey, 1980) and quartz. The two more Ni-rich samples (F2 and F3) contain traces of the variety of talc, identified as kerolite on the basis of the reflection at $9.8 \AA$ (Fig. 7) (Brindley et al., 1977, 1979).

Calculated profiles were fitted to the observed random XRD data (Rietveld method) in order to quantify the amount of sepiolite, quartz and kerolite present, and to refine the cell parameters and the mean crystallite size. In the Rietveld method, when a suitable instrumental profile is introduced to the refinement procedure, the crystallite size is a refined parameter that takes into account all the reflections in the pattern. The presence of quartz in the powdered samples is useful as a natural standard in the calculation of the sepiolite cell refined parameters. Fig. 8 shows the observed, calculated and difference profiles of sample F3. The refined cell parameters of sepiolite-falcondoite for samples F0, F1, F2, and F3 are similar (Table 1). The cell parameters for sample F0 with $3.68 \mathrm{wt} \% \mathrm{NiO}$, as determined on the bulk sample (Table 2), closely match those determined by Post et al. (2007) for a very pure sample of natural sepiolite (Table 1). As the Ni content increases from sample F0 to sample F3 a clear reduction in the $a$ cell-parameter only is observed. Compared with those of pure sepiolite, the average $a$ parameter for samples F0 to F3 is reduced by $0.25 \%$, whereas $b$ and $c$ are reduced by 0.08 and $0.16 \%$ respectively. This behaviour is expected on account of the larger ionic radius of $\mathrm{Mg}^{2+}$ compared with that of $\mathrm{Ni}^{2+}$ (Mg: $0.72 \AA$ and Ni: $0.69 \AA$; Shannon, 1976). The unequal relative reduction of $b$ and $c$ is also observed in the brucite $\mathrm{Mg}(\mathrm{OH})_{2}$ and theophrastite $\mathrm{Ni}(\mathrm{OH})_{2}$ structures (Brindley \& Kao, 1984; Greaves \& Thomas, 1986), where the substitution of $\mathrm{Mg}$ by $\mathrm{Ni}$ produces a reduction of $3.64 \%$ normal to octahedral sheets ( $a$ parameter in sepiolite) and $0.95 \%$ parallel to the sheets ( $b$ and $c$ in sepiolite).

The cell parameters refined for kerolite, with a basal spacing of $9.85 \AA$, are equal in the two samples F2 and F3 and consistent within the calculated errors (Table 1).

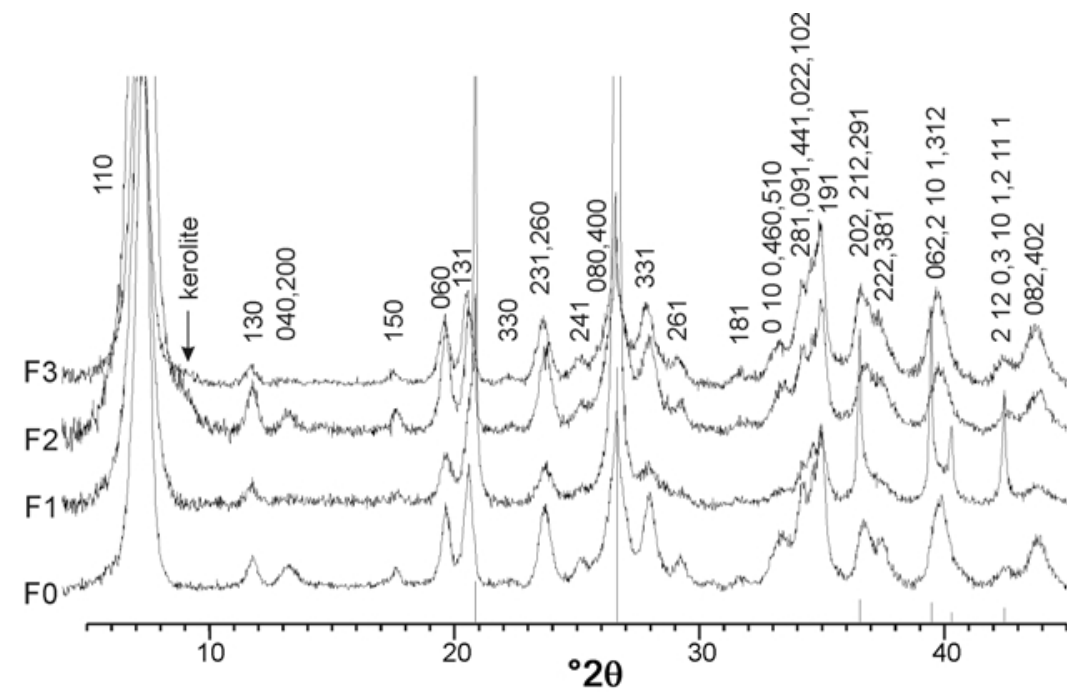

FIG. 7. XRD patterns for samples F0, F1, F2 and F3 with Miller indices of the reflections for sample F3. Samples arranged in order of increasing $\mathrm{Ni}$ content. Indexation based on the Bragg positions and calculated structure factor. Vertical black lines correspond to quartz (pattern PDF nº 00046 1045). 


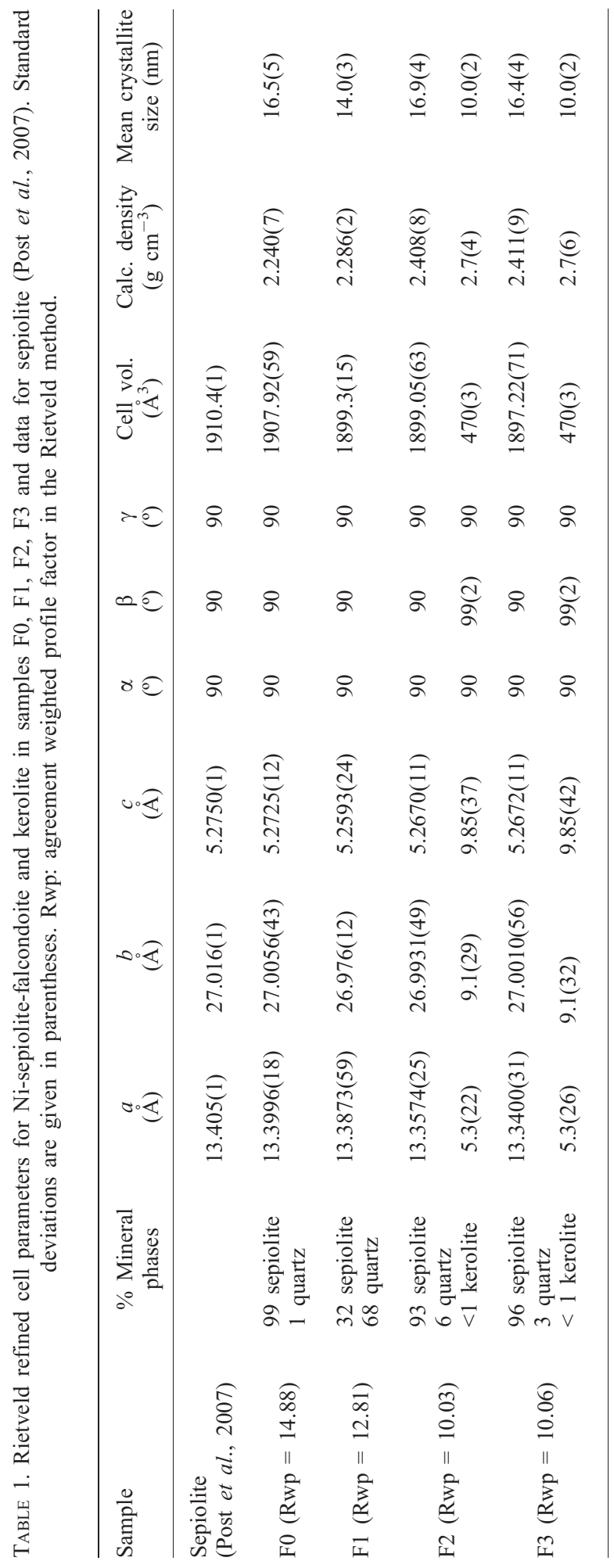




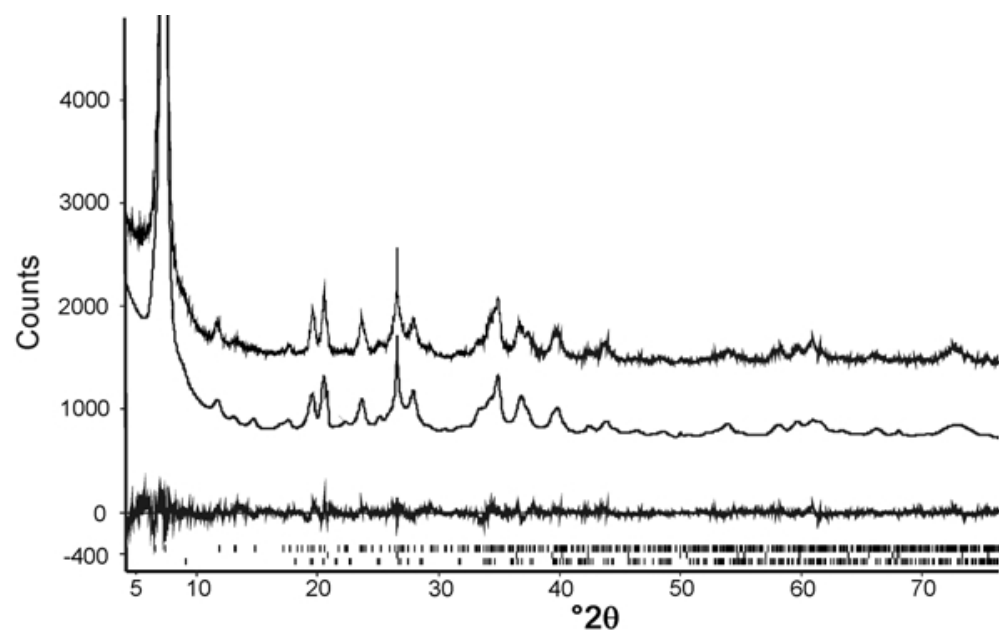

FIG. 8. XRD profile refinement of sample F3. Experimental (top), calculated Ni-sepiolite-falcondoite (middle) and difference (bottom) profiles. At the base of the diagram, the Bragg positions for the Ni-sepiolite-falcondoite, quartz and kerolite are shown.

The mean crystallite size (coherent scattering domain) obtained by the Rietveld method for the four analysed samples of Ni-sepiolite-falcondoite is around $16 \mathrm{~nm}$ (Table 1). In comparison, the calculated average crystallite size of intercalated quartz is $150 \mathrm{~nm}$.

XRD patterns of the oriented-mounts of samples showed a slight expansion in the (110) reflection from $\sim 11.9 \AA$ to $12.1 \AA$ after treatment with ethylene glycol. This is the same as reported for sepiolite (Yalçin \& Bozkaya,1995; Karakaya et al., 2004). A change in the $d$ spacing of the (400) peak from $3.33 \AA$ (air-dry) to $3.42 \AA$ (ethylene glycol), is similar to the behaviour observed for sepiolite by Van de Heuvel (in Thorez, 1975). Heating to $550^{\circ} \mathrm{C}$ confirmed the formation of the anhydrous sepiolite structure with spacing at $\sim 10.4$ and $8.2 \AA$. (Jones \& Galán, 1988; Nagata et al., 1974; Post et al., 2007) (Fig. 9). It was also observed that in the most Nirich samples, F2 and F3, the (110) reflection at

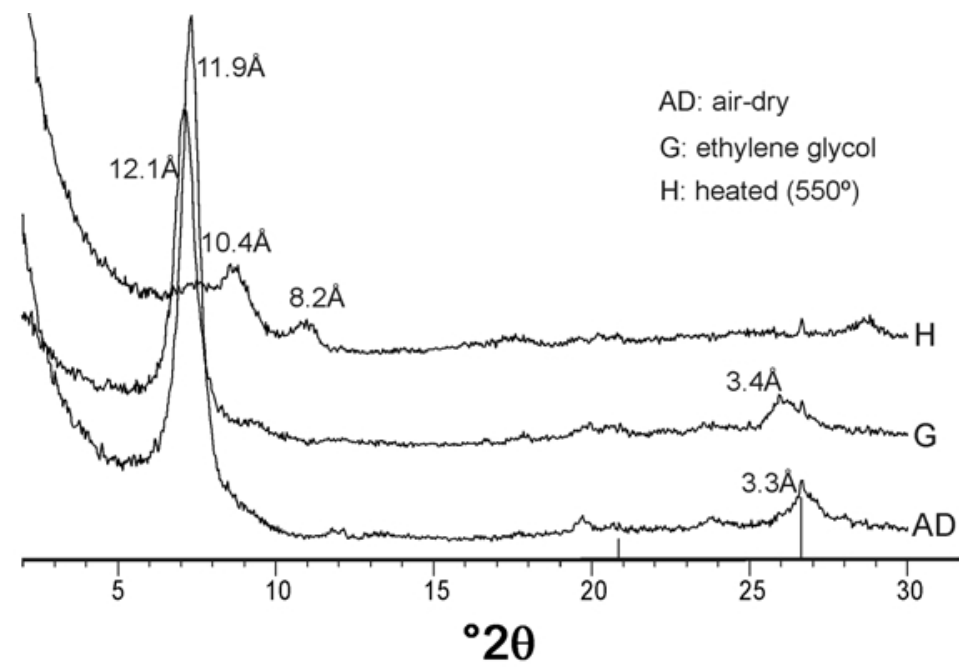

FIG. 9. XRD patterns of oriented mounts of sample F2 as (a) air-dry specimen (b) saturated with ethylene glycol and (c) heated to $550^{\circ} \mathrm{C}$. Vertical black lines correspond to quartz (pattern $\mathrm{n}^{\circ} 000461045$ ). 
$\sim 11.9 \AA$ remains as a broad peak with low intensity after $4 \mathrm{~h}$ at $550^{\circ} \mathrm{C}$.

\section{Mineral chemistry}

The chemical composition of powders of samples F0, F1, F2, F3, F6 and F7 of Ni-sepiolitefalcondoite measured by XRF are listed in Table 2. Since the amount of quartz present is known in each of the samples from XRD results, the excess silica can be subtracted from the chemical analyses, and the composition of Nisepiolite-falcondoite in the samples calculated (Table 2). With these corrected data, the average formulae can be determined (Table 2). The $\mathrm{SiO}_{2}$ content is between 51.08 and 55.34 wt.\%, $\mathrm{MgO}$ is between 14.58 and 23.7 wt.\% and $\mathrm{NiO}$ is between 1.95 and $15.77 \mathrm{wt} . \%$. The structural formulae calculated with these values can be considered unequivocally as $\mathrm{Ni}$-sepiolite.

The Ni-sepiolite-falcondoite samples F0, F1, F2, F3 and G1 were analysed in situ by EMP. Examination of the areas on the polished thin sections to be analysed by reflected light microscopy and SEM showed an adequate polish and absence of impurities at the scale of observation. Selected electron microprobe analyses of Ni-sepiolite-falcondoite are listed in Table 3, and 86 point analyses are plotted in the triangular $\mathrm{Mg}$ Si-Ni diagram (Fig. 10).

Chemical compositions of all the analysed samples cover a large interval of Ni-sepiolitefalcondoite between $\mathrm{Fal}_{3}$ and $\mathrm{Fal}_{77}$. The smallest amount of $\mathrm{NiO}$ measured by the microprobe in the samples examined was 1.43 wt.\%, in F0. This sample showed only a narrow range in composition from 1.43 to $3.53 \mathrm{wt} . \% \mathrm{NiO}$, consistent with the slight variation of colour from white to very pale green in hand specimen. In contrast, the variation in $\mathrm{NiO}$ in the more falcondoite-rich samples showed the widest range, with $\mathrm{NiO}$ ranging from 4.63 to 22.4 wt.\% in $\mathrm{F} 2$ and from 11.35 to 27.89 wt. $\%$ in F3. The greatest $\mathrm{NiO}$ measured by the microprobe is $30.42 \mathrm{wt} . \%$ in sample G1. The amounts of Fe, $\mathrm{Al}, \mathrm{Cr}, \mathrm{Ti}, \mathrm{Ca}, \mathrm{Na}$ and $\mathrm{K}$ are very small or below the detection limit. $\mathrm{Fe}$ and $\mathrm{Al}$ are $<0.05 \mathrm{wt} . \%$ in most of the EMP analyses determined at a beam diameter of $\sim 1 \mu \mathrm{m}$, indicating that the amounts of

TABLE 2. Major element analyses (XRF) of the Ni-sepiolite-falcondoite studied samples (F0, F1, F2, F3, F6 and F7), corrected silica analyses and average structural formulae. Standard deviations are given in parentheses.

\begin{tabular}{|c|c|c|c|c|}
\hline XRF & $\mathrm{SiO}_{2}$ & $\mathrm{MgO}$ & $\mathrm{NiO}$ & Total anhydrous \\
\hline \multicolumn{5}{|c|}{ Whole-rock sample } \\
\hline F0 & $54.74(0.31)$ & $21.83(0.32)$ & $3.68(0.21)$ & 80.25 \\
\hline F1 & $88.79(0.40)$ & $3.95(0.14)$ & $1.45(0.13)$ & 94.19 \\
\hline F2 & $57.55(0.32)$ & $13.31(0.25)$ & $10.52(0.36)$ & 81.38 \\
\hline F3 & $52.34(0.31)$ & $14.76(0.26)$ & $15.95(0.44)$ & 83.05 \\
\hline F6 & $66.55(0.34)$ & $26.92(0.36)$ & $2.22(0.17)$ & 95.69 \\
\hline F7 & $64.03(0.34)$ & $10.79(0.23)$ & $10.83(0.37)$ & 85.65 \\
\hline \multicolumn{5}{|c|}{ Sepiolite-falcondoite percent, after substraction of excess silica } \\
\hline Fo & 54.76 & 22.41 & 3.78 & 80.95 \\
\hline F1 & 53.74 & 20.08 & 7.34 & 81.16 \\
\hline $\mathrm{F} 2$ & 52.51 & 16.63 & 13.01 & 82.15 \\
\hline F3 & 51.08 & 14.58 & 15.77 & 81.43 \\
\hline F6 & 55.34 & 23.70 & 1.95 & 80.99 \\
\hline F7 & 51.84 & 15.02 & 15.10 & 81.96 \\
\hline \multicolumn{5}{|c|}{ mula for sepiolite-falcondoite } \\
\hline \multicolumn{5}{|c|}{$\mathrm{F} 0\left[\mathrm{Mg}_{7.32} \mathrm{Ni}_{0.67} \mathrm{Si}_{12} \mathrm{O}_{30}(\mathrm{OH})_{4}\left(\mathrm{OH}_{2}\right)_{4} \cdot 8\left(\mathrm{H}_{2} \mathrm{O}\right)\right]$} \\
\hline \multicolumn{5}{|c|}{$\mathrm{F} 1\left[\mathrm{Mg}_{6.68} \mathrm{Ni}_{1.32} \mathrm{Si}_{12} \mathrm{O}_{30}(\mathrm{OH})_{4}\left(\mathrm{OH}_{2}\right)_{4} .8\left(\mathrm{H}_{2} \mathrm{O}\right)\right]$} \\
\hline \multicolumn{5}{|c|}{$\mathrm{F} 2\left[\mathrm{Mg}_{5.66} \mathrm{Ni}_{2.39} \mathrm{Si}_{12} \mathrm{O}_{30}(\mathrm{OH})_{4}\left(\mathrm{OH}_{2}\right)_{4} .8\left(\mathrm{H}_{2} \mathrm{O}\right)\right]$} \\
\hline \multicolumn{5}{|c|}{$\mathrm{F} 3\left[\mathrm{Mg}_{5.04} \mathrm{Ni}_{2.94} \mathrm{Si}_{12} \mathrm{O}_{30}(\mathrm{OH})_{4}\left(\mathrm{OH}_{2}\right)_{4} .8\left(\mathrm{H}_{2} \mathrm{O}\right)\right]$} \\
\hline \multicolumn{5}{|c|}{ F6 $\left[\mathrm{Mg}_{7.66} \mathrm{Ni}_{0.34} \mathrm{Si}_{12} \mathrm{O}_{30}(\mathrm{OH})_{4}\left(\mathrm{OH}_{2}\right)_{4} .8\left(\mathrm{H}_{2} \mathrm{O}\right)\right]$} \\
\hline \multicolumn{5}{|c|}{$\mathrm{F} 7\left[\mathrm{Mg}_{5.18} \mathrm{Ni}_{2.81} \mathrm{Si}_{12} \mathrm{O}_{30}(\mathrm{OH})_{4}\left(\mathrm{OH}_{2}\right)_{4} .8\left(\mathrm{H}_{2} \mathrm{O}\right)\right]$} \\
\hline
\end{tabular}


these two elements are negligible in the $\mathrm{Ni}$ - $\mathrm{Si}$ ratio varies from 0.6 to 0.75 , to be compared sepiolite-falcondoite structure.

The structural formulae calculated on the basis of structural formula $(\mathrm{Mg}, \mathrm{Ni})_{8} \mathrm{Si}_{12} \mathrm{O}_{30}$ $\mathrm{O}_{30}(\mathrm{OH})_{4}$ are also given in Table 3. The $(\mathrm{Ni}+\mathrm{Mg}) /(\mathrm{OH})_{4}\left(\mathrm{OH}_{2}\right)_{4} \cdot 8\left(\mathrm{H}_{2} \mathrm{O}\right)$. In most of the analyses, the

TABLE 3. Selected electron microprobe compositions of sepiolite-falcondoite samples along with the calculated structural formulae for samples from the Falcondo Ni-laterite deposit. Analyses (wt.\%) are reported in order of increasing $\mathrm{NiO}$ content.

\begin{tabular}{|c|c|c|c|c|c|c|c|c|c|c|c|}
\hline Sample & $\mathrm{SiO}_{2}$ & $\mathrm{Al}_{2} \mathrm{O}_{3}$ & $\mathrm{FeO}$ & $\mathrm{MgO}$ & $\mathrm{NiO}$ & $\mathrm{Cr}_{2} \mathrm{O}_{3}$ & $\mathrm{MnO}_{2}$ & $\mathrm{~K}_{2} \mathrm{O}$ & $\mathrm{CaO}$ & $\mathrm{Na}_{2} \mathrm{O}$ & Total \\
\hline $1 \mathrm{~F} 0$ & 59.14 & 0.04 & 0.10 & 22.72 & 2.06 & 0.04 & 0.05 & 0.06 & 0.00 & 0.02 & 84.23 \\
\hline $2 \mathrm{~F} 0$ & 56.62 & 0.07 & 0.10 & 22.02 & 2.37 & 0.02 & 0.00 & 0.08 & 0.00 & 0.01 & 81.29 \\
\hline $3 \mathrm{~F} 0$ & 57.65 & 0.10 & 0.60 & 20.46 & 3.17 & 0.04 & 0.02 & 0.02 & 0.03 & 0.05 & 82.16 \\
\hline $4 \mathrm{~F} 0$ & 57.88 & 0.07 & 0.62 & 21.38 & 3.33 & 0.01 & 0.03 & 0.02 & 0.01 & 0.02 & 83.40 \\
\hline $5 \mathrm{~F} 1$ & 58.82 & 0.00 & 0.04 & 22.43 & 4.12 & 0.02 & 0.00 & 0.04 & 0.09 & 0.18 & 85.74 \\
\hline 6 F1 & 56.69 & 0.02 & 0.00 & 19.82 & 5.97 & 0.00 & 0.00 & 0.07 & 0.02 & 0.13 & 82.73 \\
\hline $7 \mathrm{~F} 1$ & 55.76 & 0.05 & 0.06 & 18.32 & 6.53 & 0.00 & 0.00 & 0.06 & 0.03 & 0.18 & 81.01 \\
\hline 8 F1 & 54.39 & 0.00 & 0.02 & 17.35 & 8.56 & 0.01 & 0.07 & 0.08 & 0.01 & 0.13 & 80.62 \\
\hline $9 \mathrm{~F} 2$ & 57.32 & 0.00 & 0.00 & 17.66 & 11.59 & 0.01 & 0.04 & 0.00 & 0.00 & 0.02 & 86.65 \\
\hline $10 \mathrm{~F} 3$ & 52.28 & 0.53 & 0.08 & 14.86 & 12.25 & 0.02 & 0.01 & 0.00 & 0.00 & 0.00 & 80.03 \\
\hline $11 \mathrm{~F} 2$ & 58.41 & 0.05 & 0.00 & 16.75 & 14.13 & 0.01 & 0.00 & 0.00 & 0.00 & 0.01 & 89.37 \\
\hline $12 \mathrm{~F} 2$ & 56.07 & 0.04 & 0.03 & 14.42 & 16.06 & 0.00 & 0.00 & 0.00 & 0.00 & 0.03 & 86.66 \\
\hline $13 \mathrm{~F} 2$ & 58.52 & 0.01 & 0.01 & 14.34 & 16.95 & 0.02 & 0.02 & 0.02 & 0.00 & 0.00 & 89.89 \\
\hline $14 \mathrm{~F} 2$ & 54.52 & 0.00 & 0.00 & 12.29 & 18.96 & 0.04 & 0.00 & 0.00 & 0.00 & 0.03 & 85.85 \\
\hline $15 \mathrm{G} 1$ & 53.24 & 0.00 & 0.00 & 8.86 & 20.43 & 0.00 & 0.02 & 0.00 & 0.06 & 0.02 & 82.72 \\
\hline $16 \mathrm{~F} 2$ & 55.56 & 0.00 & 0.00 & 11.51 & 22.44 & 0.02 & 0.02 & 0.03 & 0.00 & 0.01 & 89.61 \\
\hline 17 G1 & 50.12 & 0.00 & 0.05 & 7.27 & 22.69 & 0.00 & 0.00 & 0.01 & 0.08 & 0.00 & 80.29 \\
\hline $18 \mathrm{~F} 3$ & 49.56 & 0.31 & 0.08 & 10.79 & 23.36 & 0.00 & 0.02 & 0.10 & 0.00 & 0.04 & 84.27 \\
\hline $19 \mathrm{~F} 3$ & 47.63 & 0.33 & 0.04 & 9.45 & 26.82 & 0.00 & 0.06 & 0.06 & 0.00 & 0.06 & 84.45 \\
\hline $20 \mathrm{G} 1$ & 52.04 & 0.00 & 0.00 & 6.58 & 26.93 & 0.00 & 0.00 & 0.00 & 0.05 & 0.01 & 85.70 \\
\hline $21 \mathrm{G} 1$ & 52.70 & 0.00 & 0.00 & 2.93 & 32.93 & 0.00 & 0.00 & 0.03 & 0.05 & 0.05 & 88.71 \\
\hline Sample & $\mathrm{Si}$ & $\mathrm{Al}$ & $\mathrm{Fe}$ & $\mathrm{Mg}$ & $\mathrm{Ni}$ & $\mathrm{Cr}$ & $\mathrm{Mn}$ & $\Sigma$ oct & $\mathrm{K}$ & $\mathrm{Ca}$ & $\mathrm{Na}$ \\
\hline $1 \mathrm{~F} 0$ & 12.29 & 0.02 & 0.02 & 7.04 & 0.34 & & & 7.40 & & & \\
\hline $2 \mathrm{~F} 0$ & 12.22 & 0.04 & 0.02 & 7.08 & 0.41 & & & 7.51 & & & \\
\hline $3 \mathrm{~F} 0$ & 12.36 & 0.05 & 0.11 & 6.54 & 0.55 & & & 7.19 & & & \\
\hline $4 \mathrm{~F} 0$ & 12.34 & 0.03 & 0.11 & 6.75 & 0.57 & & & 7.43 & & & \\
\hline $5 \mathrm{~F} 1$ & 12.18 & & & 6.92 & 0.63 & & & 7.55 & & 0.02 & \\
\hline $6 \mathrm{~F} 1$ & 12.27 & 0.01 & 0.01 & 6.40 & 1.22 & & & 7.63 & & & \\
\hline 7 F1 & 12.36 & 0.03 & & 6.05 & 1.24 & & & 7.30 & & 0.01 & \\
\hline $8 \mathrm{~F} 1$ & 12.30 & & & 5.85 & 1.04 & & & 6.89 & & & \\
\hline $9 \mathrm{~F} 2$ & 12.20 & & 0.01 & 5.61 & 2.82 & & & 8.43 & & & \\
\hline $10 \mathrm{~F} 3$ & 12.08 & 0.29 & & 5.12 & 1.98 & & & 7.10 & & & \\
\hline $11 \mathrm{~F} 2$ & 12.19 & 0.02 & & 5.21 & 2.37 & & & 7.58 & & & \\
\hline $12 \mathrm{~F} 2$ & 12.23 & 0.02 & 0.01 & 4.69 & 2.94 & & & 7.65 & & & \\
\hline $13 \mathrm{~F} 2$ & 12.31 & & & 4.50 & 2.87 & & & 7.37 & & & \\
\hline $14 \mathrm{~F} 2$ & 12.23 & & & 4.11 & 3.42 & & & 7.53 & & & \\
\hline $15 \mathrm{G} 1$ & 12.51 & & & 3.10 & 3.86 & & & 6.96 & 0.02 & & \\
\hline $16 \mathrm{~F} 2$ & 12.15 & & & 3.75 & 3.95 & & & 7.70 & & & \\
\hline $17 \mathrm{G} 1$ & 12.39 & & 0.01 & 2.68 & 4.51 & & & 7.20 & 0.02 & & \\
\hline $18 \mathrm{~F} 3$ & 11.73 & 0.17 & 0.02 & 3.81 & 4.45 & & & 8.27 & & & \\
\hline $19 \mathrm{~F} 3$ & 11.54 & 0.19 & 0.01 & 3.41 & 5.22 & & & 8.64 & & & \\
\hline $20 \mathrm{G} 1$ & 12.28 & & & 2.31 & 5.11 & & & 7.43 & 0.01 & & \\
\hline $21 \mathrm{G} 1$ & 12.37 & & & 1.03 & 6.22 & & & 7.24 & 0.01 & & \\
\hline
\end{tabular}




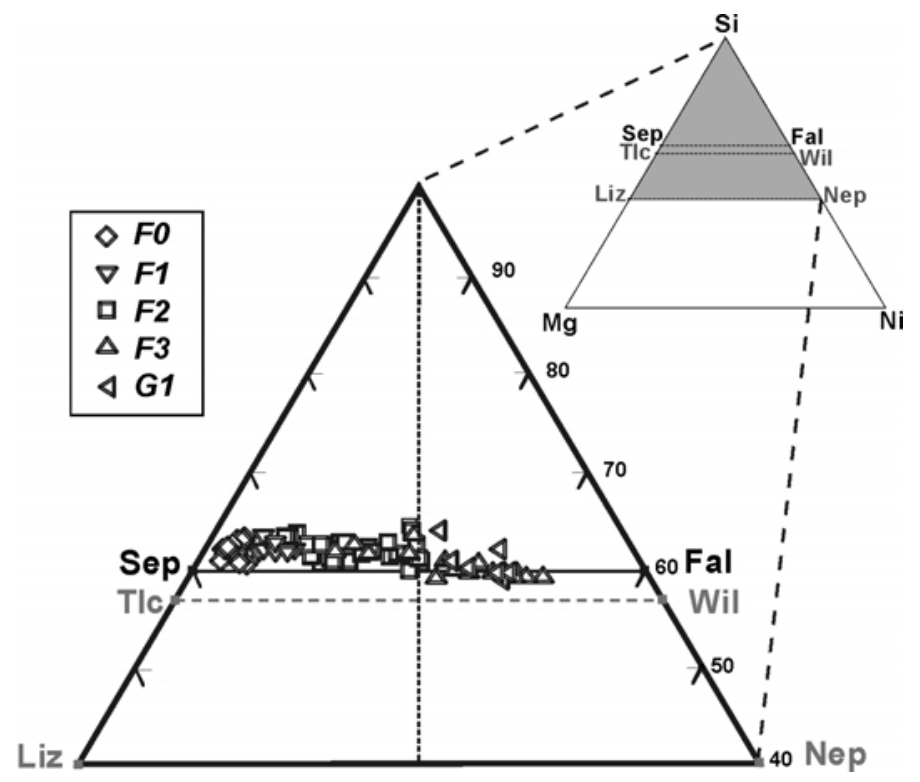

FIG. 10. Projection of sepiolite-falcondoite composition (at. \%) in Si-Ni-Mg ternary diagram. The figure also indicates the positions of the solid solution series between sepiolite-falcondoite, talc-willemseite and lizarditenepouite (Springer, 1974; Brand et al., 1998).

TABLE 4. Selected AEM structural formulae for samples from the Falcondo Ni-laterite deposit.

\begin{tabular}{|c|c|c|c|c|c|c|c|c|c|c|c|}
\hline Sample & $\mathrm{Si}$ & $\mathrm{Al}$ & $\mathrm{Fe}$ & $\mathrm{Mg}$ & $\mathrm{Ni}$ & Co & $\mathrm{Cr}$ & $\mathrm{Mn}$ & Soct. & $\mathrm{Ca}$ & $\mathrm{K}$ \\
\hline $1 \mathrm{~F} 0$ & 12.14 & 0.07 & 0.01 & 7.32 & 0.19 & 0.01 & 0.02 & 0.03 & 7.65 & & \\
\hline $2 \mathrm{~F} 0$ & 12.37 & & 0.04 & 6.84 & 0.28 & 0.04 & 0.02 & & 7.22 & & \\
\hline $3 \mathrm{~F} 0$ & 12.03 & 0.03 & 0.02 & 7.43 & 0.39 & 0.02 & 0.02 & & 7.91 & & \\
\hline $4 \mathrm{~F} 0$ & 12.09 & 0.01 & & 7.26 & 0.55 & & & & 7.82 & & \\
\hline $5 \mathrm{~F} 0$ & 12.03 & 0.02 & 0.01 & 7.32 & 0.56 & & & & 7.91 & 0.01 & \\
\hline $6 \mathrm{~F} 0$ & 12.05 & 0.03 & 0.03 & 6.93 & 0.82 & & & 0.03 & 7.84 & 0.02 & \\
\hline $7 \mathrm{F0}$ & 12.20 & 0.03 & 0.02 & 6.60 & 0.87 & & 0.03 & 0.01 & 7.56 & 0.02 & \\
\hline 8 F0 & 12.22 & 0.04 & & 6.49 & 0.97 & & 0.02 & & 7.52 & 0.01 & 0.01 \\
\hline $9 \mathrm{~F} 3$ & 12.14 & 0.09 & 0.01 & 6.39 & 1.13 & & 0.02 & 0.01 & 7.65 & 0.02 & \\
\hline $10 \mathrm{~F} 0$ & 12.21 & 0.08 & 0.01 & 6.25 & 1.17 & & & & 7.51 & 0.02 & \\
\hline $11 \mathrm{~F} 0$ & 12.28 & 0.02 & & 6.13 & 1.24 & & 0.02 & 0.02 & 7.43 & & \\
\hline $12 \mathrm{~F} 2$ & 12.16 & 0.04 & & 5.94 & 1.64 & & 0.02 & 0.02 & 7.66 & & 0.01 \\
\hline $13 \mathrm{~F} 2$ & 12.29 & 0.01 & & 5.61 & 1.76 & & 0.01 & & 7.39 & & \\
\hline $14 \mathrm{~F} 2$ & 12.22 & 0.01 & & 5.74 & 1.78 & & & 0.02 & 7.55 & & \\
\hline $15 \mathrm{~F} 3$ & 12.61 & 0.26 & & 4.02 & 1.85 & 0.06 & 0.14 & 0.06 & 6.39 & 0.16 & 0.02 \\
\hline $16 \mathrm{~F} 3$ & 12.30 & 0.02 & & 5.32 & 2.04 & & 0.01 & & 7.39 & & \\
\hline $17 \mathrm{~F} 2$ & 12.23 & 0.06 & 0.01 & 5.21 & 2.21 & & & & 7.49 & 0.01 & \\
\hline $18 \mathrm{~F} 2$ & 12.33 & 0.05 & 0.02 & 4.59 & 2.54 & 0.02 & 0.04 & & 7.26 & 0.03 & \\
\hline $19 \mathrm{~F} 7$ & 12.07 & & & 5.07 & 2.69 & & 0.04 & & 7.82 & 0.01 & \\
\hline $20 \mathrm{~F} 2$ & 12.48 & 0.02 & & 4.30 & 2.71 & & & & 7.03 & & \\
\hline $21 \mathrm{~F} 7$ & 11.98 & 0.02 & & 4.23 & 3.53 & & & 0.05 & 7.93 & & \\
\hline $22 \mathrm{~F} 7$ & 12.03 & & & 3.41 & 3.84 & 0.02 & 0.13 & & 7.40 & & \\
\hline $23 \mathrm{~F} 7$ & 12.09 & & & 2.89 & 4.67 & & 0.03 & & 7.59 & & \\
\hline
\end{tabular}


sum of tetrahedral cations exceeds 12 . Taking into account that it is not possible for the tetrahedral positions to be filled by more than $12 \mathrm{Si}$ atoms per unit cell, the excess silica can be explained by contamination of amorphous spheres of silica intergrown with the Ni-sepiolite-falcondoite (see Fig. 5c). The sum of octahedral cations in the formulae of the majority of the EMP analyses does not exceed the value of eight.

AEM analyses were performed by EDX-TEM on fibres of Ni-sepiolite-falcondoite in samples F0, F2, F3, F6 and F7. The structural formulae for selected analysed particles, calculated on the basis of 32 oxygens, are presented in Table 4. In general the data obtained by AEM display a continuous variation in composition in each of the samples similar to the data obtained by microprobe analysis. Octahedral occupancy ranges from 7.25 to 7.93 a.p.f.u. The octahedral $\mathrm{Mg}$ number ranges from 2.89 to 7.93 , whereas the octahedral $\mathrm{Ni}$ number varies form 0.02 to 4.67 . Si is the dominant cation in the tetrahedral site, and in some cases is in slight excess of 12 (11.89-12.10 a.p.f.u.). Nisepiolite-falcondoite particles are poor in $\mathrm{Fe}, \mathrm{Al}$, $\mathrm{Cr}, \mathrm{Co}, \mathrm{Ca}, \mathrm{Na}$ and $\mathrm{K}$.

In Fig. 11 the positions of four points analysed along two fibres are shown, along with the calculated structural formulae. The composition at each point is different and shows that there is a compositional heterogeneity in terms of $\mathrm{Mg} / \mathrm{Ni}$ ratio from one adjacent fibre to another and also within single fibres.

\section{$T G$ analyses}

Studies of the thermal behaviour of sepiolite reviewed by Jones \& Galán (1988) have shown that TGA curves can be evaluated over three temperature regions. These are: (1) A strong endothermic peak in the low-temperature region $\left(<300^{\circ} \mathrm{C}\right)$ that corresponds to the loss of adsorbed and zeolitic water, and probably to the beginning of the loss of coordinated water (Frost \& Ding, 2003). Weight losses during this interval are variable. (2) Two thermal peaks in the central-temperature region $\left(300-600^{\circ} \mathrm{C}\right)$ corresponding to the loss of coordinated water which have been investigated in detail by Nagata et al. (1974). (3) In the high-temperature region $\left(>600^{\circ} \mathrm{C}\right)$ it is common to observe an endothermic peak at about $800^{\circ} \mathrm{C}$ immediately followed by an exothermic maximum. These peaks correspond to dehydroxylation of the structure and to the formation of clinopyroxene, respectively (Jones \& Galán, 1988).

The thermal behaviour of the same four powders (F0, F1, F2 and F3) studied by XRD yielded almost identical results that closely match the data for sepiolite obtained by other workers and for the sample of falcondoite examined by Springer (1976).

The results of TGA of samples F0 and F3 are listed in Table 5, and the TGA curve of sample F3 with the four intervals of loss of water is shown in Fig. 12. The total weight loss $(\sim 17 \mathrm{wt} . \%)$ for the TG analyses of sample F3 agrees well with the values obtained by Springer (1976) for a falcondoite sample but differs slightly from those measured by Nagata et al. (1974), Balci (1996) and Frost \& Ding (2003), for pure sepiolite (Table 5). If the ideal formula for the sepiolite structure is taken into account, $\left[\mathrm{Mg}_{8} \mathrm{Si}_{12} \mathrm{O}_{30}\right.$ $\left.(\mathrm{OH})_{4}\left(\mathrm{OH}_{2}\right)_{4} .8\left(\mathrm{H}_{2} \mathrm{O}\right)\right]$ and for falcondoite $\left[\mathrm{Ni}_{8} \mathrm{Si}_{12} \mathrm{O}_{30}(\mathrm{OH})_{4}\left(\mathrm{OH}_{2}\right)_{4} \cdot 8\left(\mathrm{H}_{2} \mathrm{O}\right)\right]$, it is possible to

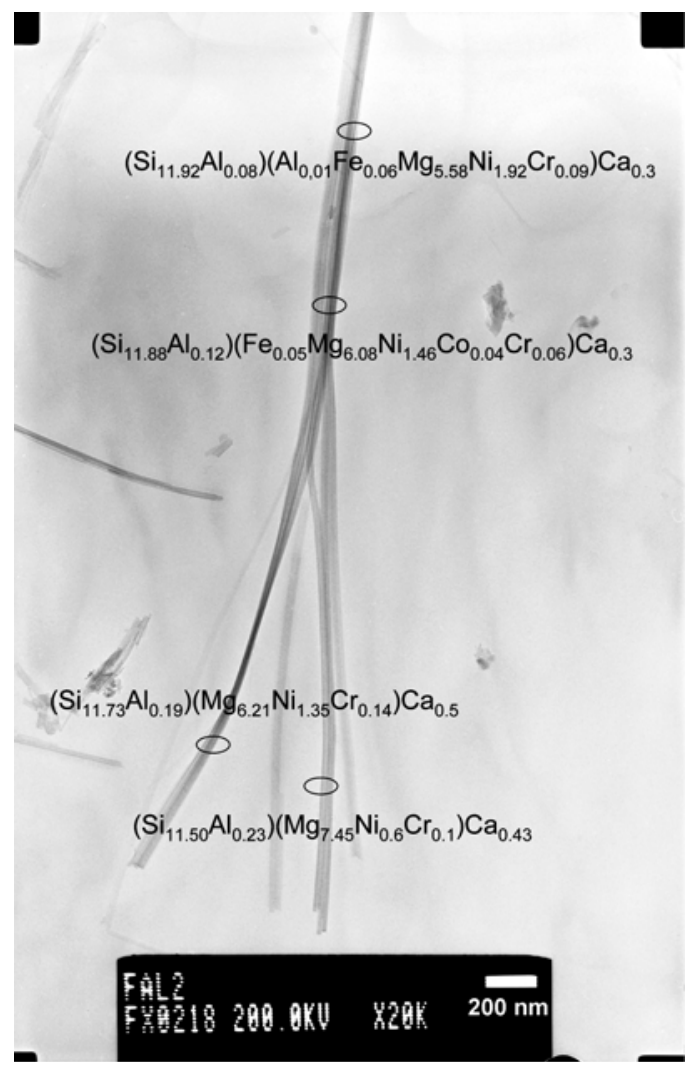

FIG. 11. TEM image shows the position of four AEM analyses along two Ni-sepiolite fibres. 
calculate, the theoretical percentages of loss of water corresponding to each stage for both (Table 5). For example, given the mean structural formula obtained for sample $\mathrm{F} 3$ by XRF $\left[\mathrm{Mg}_{5.04} \mathrm{Ni}_{2.94} \mathrm{Si}_{12} \mathrm{O}_{30}(\mathrm{OH})_{4}\left(\mathrm{OH}_{2}\right)_{4} .8\left(\mathrm{H}_{2} \mathrm{O}\right)\right]$, the experimental total water loss of $\sim 17 \mathrm{wt} . \%$ represents only 13.1 water molecules (w.m.) per formula unit (p.f.u.). This is to be compared with the theoretical value of 14 , as derived from data published by Nagata et al. (1974) for natural Mg sepiolite (Table 5). This suggests that the capacity for the retention of water in the sepiolite structure diminishes with increasing nickel content. In particular, these 13.1 molecules p.f.u. distributed in the four characteristic steps of water loss in falcondoite, give values of 7.5 (8 zeolitic water molecules in ideal sepiolite), 2.03 (2 coordinated w.m.), 1.53 (2 coordinated w.m.) and 2.07 (2.0 hydroxyl w.m.). This could indicate that sample F3 retains less zeolitic and coordinated water than ideal or natural $\mathrm{Mg}$ sepiolite. Sample F0 with less Ni than sample F3 showed the same behaviour. It retained fewer water molecules than pure sepiolite but slighty more (13.5 w.m.) than sample F3 (Table 5).

The principal difference in water content in the TGA results corresponds to the coordinated and bound water, designated in the structural formulae as $\left(\mathrm{OH}_{2}\right)_{4}$. These water molecules complete the coordination of the octahedral cations at the edges of the octahedral strips.

\section{DISCUSSION}

\section{The sepiolite-falcondoite series}

Previous studies of Ni-sepiolite and falcondoite have suggested that an isomorphous series exists between these end-members (e.g. Springer, 1974, 1976; Brindley, 1978). This suggestion is consistent with our current understanding of Ni-Mg-bearing phyllosilicates in garnierite ores (e.g. Brand et al., 1998; Gleeson et al., 2003, 2004; Freyssinet et al., 2005; Wells et al., 2009; Reddy et al., 2009). According to these authors, Ni-Mg phyllosilicates [e.g. lizardite-nepouite, kerolite(talc)-pimelite (willemseite), sepiolite-falcondoite, and clinochlorenimite] can be regarded as members of a solid solution extending from $\mathrm{Mg}$ and $\mathrm{Ni}$ end members. The similarity in ionic radii and charge of $\mathrm{Mg}^{2+}$ and $\mathrm{Ni}^{2+}$ is such that many solid solution series are formed between $\mathrm{Mg}$ and $\mathrm{Ni}$ end-members. 


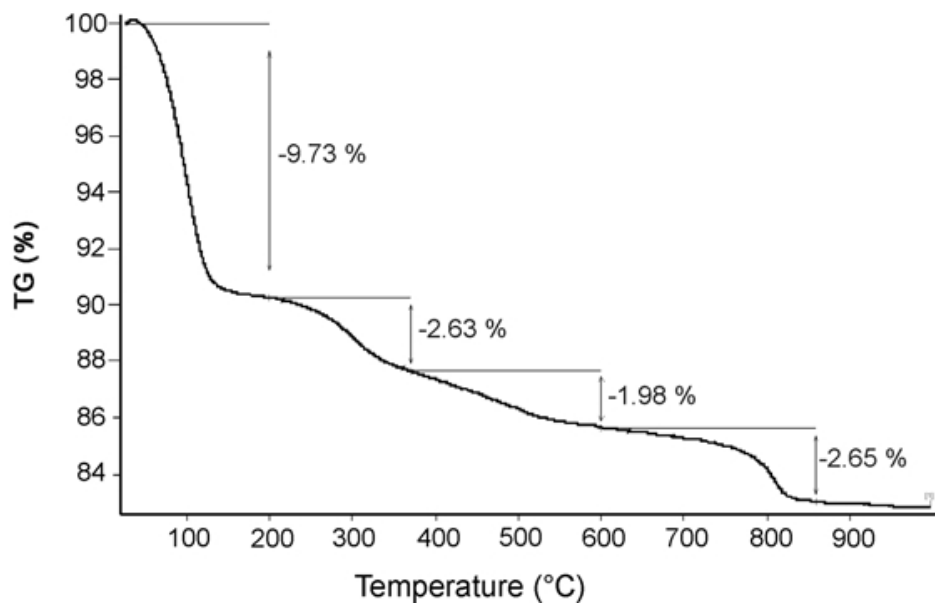

FIG. 12. TGA curve of sepiolite-falcondoite (sample F3) with loss of water for the four steps (see Table 5 and text for explanation).

However, few data exist on the mechanism of Ni$\mathrm{Mg}$ substitution. The analyses of Ni-phyllosilicates by Extended X-ray Absorption Fine Structure of Ni hydrosilicates (Manceau \& Calas, 1985) indicates that the distribution of $\mathrm{Ni}$ in the octahedral sheet is heterogeneous and the $\mathrm{Ni}$ atoms are segregated (clustered) into discrete domains. Spectroscopic studies have shown that many solid solutions, which were considered to be random, have a heterogeneous structure on a scale of several $\AA$ (Manceau, 1990). In fact, Ni clustering has been described in all natural Ni-bearing phyllosilicates studied, including $\mathrm{Ni}$ sepiolite (Manceau et al., 1985, Manceau \& Calas, 1986; Manceau, 1990).

The falcondoite end-member of the sepiolitefalcondoite solid solution, $\left[\mathrm{Ni}_{8} \mathrm{Si}_{12} \mathrm{O}_{30}\right.$ $\left.(\mathrm{OH})_{4}\left(\mathrm{OH}_{2}\right)_{4} \cdot 8\left(\mathrm{H}_{2} \mathrm{O}\right)\right]$, has not yet been found in nature. The samples analysed by Springer (1976) contained significant amounts of the sepiolite component. The chemical compositions of the samples analysed in this work do not include the pure $\mathrm{Ni}$ analogue of sepiolite, either. However, the chemical compositions cover a large interval of Nisepiolite-falcondoite $\left(\mathrm{Fal}_{3}\right.$ and $\left.\mathrm{Fal}_{77}\right)$. Changes in $\mathrm{Ni}$ and $\mathrm{Mg}$ contents were gradual in the different generations of Ni-sepiolite, suggesting a continuum of $\mathrm{Ni}$ for $\mathrm{Mg}$ solid solution between sepiolite and falcondoite, at least on the scale analysed by the microprobe. The close association of sepiolitefalcondoite could be due to the gradual change from one composition to the other in response to the Ni-for-Mg solid-solution continuum, the growth conditions being related to processes of supergene enrichment of $\mathrm{Ni}$ in the lateritic environment.

Nevertheless, the spatial homogeneity of the solid solution is reduced, so that points separated by only about several tenths of a $\mu \mathrm{m}$ yield different $\mathrm{Ni}$ contents, as has been observed by both EMP and EDX-TEM analyses. Accordingly, the samples used in the XRD were not homogeneous in chemical composition, and the results obtained after the Rietveld refinements have to be taken as average values in relation to the compositions of the same powders analysed by XRF and TGA. The $a$ parameter displays a clear almost linear correlation with the Ni content, that can be expressed by the equation $a=13.405-0.0042 \cdot X_{\mathrm{Ni}}\left(\mathrm{R}^{2}=0.959\right)$. This clearly indicates a reduction normal to the sepiolite-brucite ribbons with the Ni content. A similar correlation has not been found for $b$ and $c$ parameters, since they display erratic variations with the Ni content. Only the average of $b$ and $c$ over the samples F0 to F3 suggest a very small reduction with increase in $\mathrm{Ni}$.

\section{Origin of the Ni-sepiolite-falcondoite-type garnierites}

The Dominican Ni-laterite deposits are classified as the hydrous silicate-type and the main Ni-bearing minerals are hydrated $\mathrm{Mg}-\mathrm{Ni}$ silicates occurring deeper in the profile (saprolitized peridotite). Dominican laterites, as well as other silicate-type laterites, can be formed where there is slow 
continuous tectonic uplift and the water table is kept low in the profile. In this situation, weathering over long periods can result in the development of a thick saprolite horizon (Golightly, 1981; Brand et al., 1998; Elias, 2002; Gleeson et al., 2003; Lewis et al., 2006). During weathering, the main Ni-containing primary silicates (olivine and serpentine) are altered in oxidizing conditions. The $\mathrm{Mg}$ is highly soluble and removed from the weathering profile. The Fe content in sepiolite and falcondoite is always very small $(<0.5$ wt. $\% \mathrm{FeO})$ and represents an impurity, indicating that Ni-sepiolite-falcondoite crystallizes when most of the $\mathrm{Fe}$ has been oxidized to $\mathrm{Fe}^{3+}$, and fixed as highly insoluble goethite, mainly at the upper limonite zone of the laterite profiles. In hydrous silicate-type lateritic profiles, as in the Dominican Republic, Ni-rich oxyhydroxides (mainly goethite) are dissolved in the upper horizons, resulting in a continuous leaching of $\mathrm{Ni}$ according to the reaction (Freyssinet et al., 2005):

$\mathrm{FeOOH}(\mathrm{Ni})(\mathrm{OH})_{2}+2 \mathrm{H}^{+}=\mathrm{FeOOH}+\mathrm{Ni}^{2+}+\mathrm{H}_{2} \mathrm{O}$ goethite with adsorbed $\mathrm{Ni}$

The Ni-rich solution is then transported downwards through the profile, re-precipitating at the base with $\mathrm{Si}$ and $\mathrm{Mg}$ to form garnierites, including the sepiolite-falcondoite type. The high stability of the octahedral coordination around the $\mathrm{Ni}^{2+}$ ion (Burns, 1970) favours the formation of nickeliferous trioctahedral phyllosilicates (e.g. Trescases, 1975). In alkaline conditions $(\mathrm{pH}>7.5)$ garnierite minerals (e.g. Ni-sepiolite-falcondoite) are the least-soluble $\mathrm{Mg}-\mathrm{Ni}$ phyllosilicates, whereas at lower $\mathrm{pH}$, quartz may precipitate. The occurrence of quartz replacement indicates more acidic conditions, as a result of rapid access of meteoric surface waters to deep levels (e.g. Golightly, 1981).

The extensive fracturing present in the protolith facilitates ground water penetration into the bedrock. This supergene nickel enrichment is restricted to places where water can move downward in the saprolite profile to a very low water table (e.g. Golightly, 1981).

\section{CONCLUSIONS}

(1) Much of the garnierite mineralization in the Falcondo mine is made up of Ni-sepiolitefalcondoite solid solutions covering a large interval of compositions $\left(\mathrm{Fal}_{3}\right.$ and $\mathrm{Fal}_{77}$ ). Quartz and/or amorphous silica is an ubiquitous phase in the Nisepiolite-falcondoite samples.
(2) At least three generations with different composition of Ni-sepiolite-falcondoite are present in single samples, suggesting a complex mechanism of dissolution-precipitation of mineral phases, controlled by the physicochemical conditions of the solutions circulating in the laterite profile.

(3) There is a good correlation between the $a$ parameter and the $\mathrm{Ni}$ content in samples of $\mathrm{Ni}$ sepiolite-falcondoite and the changes in $\mathrm{Ni}$ and $\mathrm{Mg}$ contents were gradual in the different generations of $\mathrm{Ni}$-sepiolite at least on the scale analysed by microprobe, suggesting a continuous solid solution between sepiolite and falcondoite.

\section{ACKNOWLEDGMENTS}

This research has been supported financially by the Spanish projects CGL2006-07384 and CGL200609843. JAP and JFL gratefully acknowledge the help and hospitality extended by the staff at the Falcondo XSTRATA mine. The authors are also very grateful to Selahattin Kadir and an anonymous referee for their critical comments, as well as Javier Cuadros for his careful editing of the manuscript. We also acknowledge J.C. Melgarejo for fruitful discussions on microtextural features of the studied samples.

\section{REFERENCES}

Bailey S.W. (1980) Structure of layer silicates. Pp. 1-123 in: Crystal Structures of Clay Minerals and their X-ray identification (G.W. Brindley \& G. Brown, editors). Monograph, 5. Mineralogical Society, London.

Balci S. (1996) Thermal decomposition of sepiolite and variations in pore structure with and without acid pre-treatment. Journal of Chemical Technology and Biotechnology, 66, 72-78.

Brand N.W., Butt C.R.M. \& Elias M. (1998) Nickel laterites: classification and features. Journal of Australian Geology and Geophysics, 17, 81-88.

Brauner K \& Preisinger A. (1956) Struktur und Enstehung des Sepioliths. Tschermaks Mineralogische und Petrographische Mitteilungen, 6, 120-140.

Brindley G.W. (1978) The structure and chemistry of hydrous nickel-containing silicate and aluminate minerals. Bulletin du B.R.G.M. Section II, 3, $233-245$.

Brindley G.W. \& Kao C.C. (1984) Structural and IR relations among Brucite-like divalent metal hydroxides. Physics and Chemistry of Minerals, 10, 187-191.

Brindley G.W., Bish D.L. \& Hsien-Ming W. (1977) The 
nature of kerolite, its relation to talc and stevensite. Mineralogical Magazine, 41, 443-452.

Brindley G.W., Bish D.L. \& Wan H.M. (1979) Compositions, structures, and properties of nickelcontaining minerals in the kerolite-pimelite series. American Mineralogist, 64, 615-625.

Burns R.G. (1970) Mineralogical Applications of Crystal Field Theory. Cambridge University Press, Cambridge, U.K. p. 551.

Caillère S. (1936) Nickeliferous sepiolite . Bulletin Societe Francaise de Minéralogie, 59, 163-326.

Caillère S. \& Hénin S. (1961) Sepiolite. Pp. 325-342 in: $X$-ray Identification and Crystal Structures of Clay Minerals, $2^{\text {nd }}$ edition (G. Brown, editor) Mineralogical Society, London.

Caillère S. \& Hénin S. (1963) Minéralogie des argiles. Masson \& Cie, Paris, France. 355 pp.

Chukanova V.N., Pekov I.V., Chukanov N.V. \& Zadov A.E. (2002) Iron-rich analogue of sepiolite and the conditions of its formation in the contact aureole of the Lovozero alkaline massif. Geochemistry International, 40, 1225-1229.

Cluzel D. \& Vigier B. (2008) Syntectonic mobility of supergene nickel ores from New Caledonia (Southwest Pacific). Evidence from faulted regolith and garnierite veins. Resource Geology, 58, $161-170$.

Elias M. (2002) Nickel laterite deposits-a geological overview, resources and exploitation: Hobart, University of Tasmania, Centre for Ore Deposit Research Special Publication, 4, 205-220.

Foster L. \& Eggleton R.A. (2002) The Marlborough nickel laterite deposits. Pp. 33-36 in: Regolith and Landscape in Eastern Australia (I.C. Roach, editor). University of Canberra, Australia.

Freyssinet Ph., Butt C.R.M. \& Morris R.C. (2005) Oreforming processes related to lateritic weathering. Economic Geology, 100 th Anniversary Volume, $681-722$.

Frost R.L \& Ding Z. (2003) Controlled rate thermal analysis and differential scanning calorimetry of sepiolites and palygorskites. Thermochimica Acta, 397. 119-128.

Gleeson S.A., Butt C.R. \& Elias M. (2003) Nickel laterites: a review. SEG Newsletter, 54, 11-18.

Gleeson S.A., Herrington R.J., Durango J. \& Velázquez C.A. (2004) The mineralogy and geochemistry of the Cerro Matoso S.A. Ni-laterite deposit, Montelíbano, Colombia. Economic Geology, 99, 1197-1213.

Golightly J.P. (1981) Nickeliferous laterite deposits. Economic Geology, $75^{\text {th }}$ Anniversary Volume, 459-462.

Greaves C. \& Thomas M.A. (1986) Refinement of the structure of deuterated nickel hydroxide, $\mathrm{Ni}(\mathrm{OD})_{2}$, by powder neutron diffraction and evidence for structural disorder in samples with high surface area. Acta Crystallographica, B42, 51-55.
Haldemann E.G., Buchan R., Blowes V.H. \& Chandler T. (1979) Geology of the laterite nickel deposits, Dominican Republic. Pp. 57-84 in: International Laterite Symposium, New Orleans (D.J. Evans, R.S. Shoemaker \& H. Velman, editors). Society of Mining Engineers.

Hotz P.E. (1964) Nickeliferous laterites in southwestern Oregon and northwestern California. Economic Geology, 64, 355-396.

Jones B.F. \& Galan E. (1988) Palygorskite-sepiolite. Pp. 631-673 in: Hydrous Phyllosilicates (Exclusive of Micas) (S.W. Bailey, editor). Reviews in Mineralogy, 19, Mineralogical Society of Amererica.

Kadir S., Bas H. \& Karakas Z. (2002) Origin of sepiolite and loughlinite in a Neogene volcano-sedimentary lacustrine environment, Mihaliççk-Eskisehir, Turkey. The Canadian Mineralogist, 40, 1091-1102.

Karakaya N., Çelik Karakaya M., Temel A., Küpeli S. \& Tunoglu C. (2004) Mineralogical and chemical characterization of sepiolite occurrences at Karapinar (Konia Basin, Turquey). Clays and Clay Minerals, 52, 495-509.

Lacroix A. (1893-1895) Minéralogie de la France et de ses Colonies, I. Librairie Polytechnique Paris, France, p. 436.

Lewis J.F., Draper G., Proenza J.A., Espaillat J. \& Jimenez J. (2006) Ophiolite-related ultramafic rocks (serpentinites) in the Caribbean region: a review of their occurrence, composition, origin, emplacement and Ni-laterite soils formation. Geologica Acta, 4, 237-263.

Lithgow E.W. (1993) Nickel laterites of central Dominican Republic Part I. Mineralogy and ore dressing. Pp. 403-425 in: The Paul E. Queneau International Symposium Extractive Metallurgy of Copper, Nickel and Cobalt, Volume I: Fundamental Aspects (R.G. Reddy and R.N. Weizenbach editors). The Minerals, Metals \& Materials Society, Warrendale, Pennsylvania, USA.

Lorimer G.W. \& Cliff G. (1976) Analytical electron microscopy of minerals. Pp. 506-519 in: Electron Microscopy in Mineralogy (H.R. Wenk, editor). Springer-Verlag. Berlin.

Manceau A. (1990) Distribution of cations among the octahedral of phyllosicates: insight from EXAFS. The Canadian Mineralogist, 28, 321-328.

Manceau A. \& Calas G. (1985) Heterogeneous distribution of nickel in hydrous silicates from New Caledonia ore deposits. American Mineralogist, $\mathbf{7 0 ,}$ 549-558.

Manceau A. \& Calas G. (1986) Nickel-bearing clay minerals: II. X-ray absorption study of $\mathrm{Ni}-\mathrm{Mg}$ distribution. Clay Minerals, 21, 341-360.

Manceau A., Calas G. \& Decarreau A. (1985) Nickelbearing clay minerals: I. Optical spectroscopic study of nickel crystal chemistry. Clay Minerals, 20, 
$367-387$.

Nagata H., Shimoda S. \& Sudo T. (1974) On the dehydration of bound water of sepiolite. Clays and Clay Minerals, 22, 285-293.

Nickel E.H. (1992) Solid solutions in mineral nomenclature. Mineralogical Magazine, 56, 127-130.

Post J.E., Bish D.L. \& Heaney P.J. (2007) Synchrotron powder X-ray diffraction study of the structure and dehydration behaviour of sepiolite. American Mineralogist, 12, 91-97.

Proenza J.A., Zaccarini F., Lewis J., Longo F. \& Garuti G. (2007) Chromite composition and platinum-group mineral assemblage of PGE-rich Loma Peguera chromitites, Loma Caribe peridotite, Dominican Republic. The Canadian Mineralogist, 45, 211-228.

Proenza J.A., Lewis J.F., Galí S., Tauler E., Labrador M., Melgarejo J.C., Longo F. \& Bloise G. (2008) Garnierite mineralization from Falcondo Ni-laterite deposit (Dominican Republic). Macla, 9, 197-198.

Reddy B.J., Frost R.L. \& Dickfos M.J. (2009) Characterisation of $\mathrm{Ni}$ silicate-bearing minerals by UV-vis-NIR spectroscopy. Effect of Ni substitution in hydrous Ni-Mg silicates. Spectrochimica Acta, A71, 1762-1768

Shannon R.D. (1976) Revised effective ionic radii and systematic studies of interatomic distances in halides and chalcogenides. Acta Crystallographica, A32, 751-767.
Som S.K. \& Joshi R. (2002) Chemical weathering of serpentinite and $\mathrm{Ni}$ enrichment in $\mathrm{Fe}$ oxide at Sukinda area, Jajpur district, Orissa, India. Economic Geology, 97, 165-172.

Springer G. (1974) Compositional and structural variations in garnierites. The Canadian Mineralogist, 12, $381-388$.

Springer G. (1976) Falcondoite, nickel analogue of sepiolite. The Canadian Mineralogist, 14, 407-409.

Thorez J. (1975) Phyllosilicates and clay minerals. A laboratory handbook for their X-ray diffraction analysis. Lelotte (Dison), France, 580 pp.

TOPAS, General Profile and Structure Analysis Sofware for Powder Diffraction Data, V2.1, Bruker AXS Gmbh, Karlsruhe, Germany.

Trescases J.J. (1975) L'evolution geochimique supergene des roches ultrabasiques en zone tropicale: Formation des gisements nickeliferes de NouvelleCaledonie. Memoires O.R.S.T.O.M, Paris, 78, 259.

Wells M.A., Ramanaidou E.R., Verrall M. \& Tessarolo C. (2009) Mineralogy and crystal chemistry of 'garnierites' in the Goro lateritic nickel deposits, New Caledonia. European Journal of Mineralogy, 21, 467-483.

Yalçin H. \& Bozkaya Ö. (1995) Sepiolite-palygorskite from the Hekimhan region (Turkey). Clays and Clay Minerals, 43, 705-717. 